\title{
Refugia of marine fish in the northeast Atlantic during the last glacial maximum: concordant assessment from archaeozoology and palaeotemperature reconstructions
}

\author{
A. J. Kettle ${ }^{1}$, A. Morales-Muñiz ${ }^{2}$, E. Roselló-Izquierdo ${ }^{2}$, D. Heinrich ${ }^{3}$, and L. A. Vøllestad ${ }^{4}$ \\ ${ }^{1}$ Department of Earth Science, SUNY-Oswego, Oswego, New York, USA \\ ${ }^{2}$ Laboratorio de Arqueozoologia, Universidad Autonoma de Madrid, Madrid, Spain \\ ${ }^{3}$ Boesselstrasse 9, 24937 Flensburg, Germany \\ ${ }^{4}$ Center for Ecological and Evolutionary Synthesis, Department of Biology, University of Oslo, Oslo, Norway
}

Received: 7 June 2010 - Published in Clim. Past Discuss.: 16 July 2010

Revised: 11 January 2011 - Accepted: 28 January 2011 - Published: 3 March 2011

\begin{abstract}
Archaeozoological finds of the remains of marine and amphihaline fish from the Last Glacial Maximum (LGM) ca. 21 ka ago show evidence of very different species ranges compared to the present. We have shown how an ecological niche model (ENM) based on palaeoclimatic reconstructions of sea surface temperature and bathymetry can be used to effectively predict the spatial range of marine fish during the LGM. The results indicate that the ranges of marine fish species now in northwestern Europe were displaced significantly southwards from the modern distribution, challenging an existing paradigm of marine glacial refugia. The model presents strong evidence that there was an invasion of important fish through the Straits of Gibraltar in glacial times, where they were exploited by Palaeolithic human populations around the western Mediterranean Sea. The ENM results are important for ongoing studies of molecular ecology that aim to assess marine glacial refugia from the genetic structure of living populations, and they pose questions about the genetic identity of vanished marine populations during the LGM. Economically, the approach may be used to understand how the ranges of exploited fish species may be displaced with the future climate warming. The research presents a challenge for future archaeozoological work to delimit the glacial refugia and to verify palaeoclimatic reconstructions based on deep-sea core records.
\end{abstract}

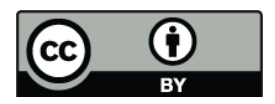

Correspondence to: A. J. Kettle (anthony.kettle@oswego.edu)

\section{Introduction}

To predict how the geographic ranges of marine species in northwest Europe will change with future climate warming, it is important to understand their environmental response characteristics and how their spatial distributions changed during the climate fluctuations of the Pleistocene glaciations. Although the spatial distribution of marine species may be largely determined by water temperatures (e.g., Kucera et al., 2005; Lenoir et al., 2010), the complicated interactions of different marine species within ecosystems - with evidence of step-like regime shifts (Beaugrand and Reid, 2003) - make predictions of future range modification difficult (Belyea, 2007). The best way to predict the future response of marine ecosystems may be to understand changes under the extreme climate conditions of the past. Much palaeoclimatic information exists for the cold conditions of the Last Glacial Maximum (LGM) ca. 21000 calender years before present (Mix et al., 2001; Sarnthein et al., 2003), as well at the midHolocene warm period 6000 years ago (Bradley, 1999), but the response of marine species across the full range of the temperature changes is not well-known. The LGM is particularly important to address this issue because it represents a situation of large perturbation of temperatures from the present condition and therefore affords the clearest picture of how marine species respond to environmental temperature change. Archaeozoology reveals important information about past climate change and corroborates palaeoclimatic information from other sources. Palaeoclimatic evidence suggests that Scandinavia was covered by glacial ice sheets, and in northern Europe permafrost conditions extended to the Massif Centrale in France with tundra conditions extending

Published by Copernicus Publications on behalf of the European Geosciences Union. 
into Spain (e.g., Butzer, 1964; Bradley, 1999). In these climatic conditions, northern terrestrial animal species ranged over western and southwestern Europe where they were utilized by human cultures, and their remains are found in the palaeolithic archaeological sites of the region (e.g., Butzer, 1964). Animal and plant species survived in glacial refugia in the Iberian peninsula, Italy, and the Balkans, and it is from these centers that Europe was recolonized during the Holocene. Genetic evidence has complemented archaeozoological evidence in elaborating on the paths of colonization for terrestrial animals, freshwater fish, and plants (e.g., Hewitt, 2000; Stewart and Lister, 2001; Provan and Bennett, 2008). For the marine fish species, there is much less information, mostly because the archaeozoological record has been lost as sea levels have risen by approximately $120 \mathrm{~m}$ since the LGM (e.g., Provan and Bennett, 2008). However, genetic studies (e.g., Maggs et al., 2008) and the sparse archaeozoological evidence indicate startling shifts in the geographic ranges of some species in response to climate change. Here, we present an overview of how the ranges of four marine and amphihaline species changed during the LGM and apply a simple ecological niche model (ENM) to explain how these altered ranges are consistent with sea surface temperature (SST) changes during the glacial period.

Identifications of fish remains from archaeological sites have revealed large changes in the ranges of some marine and amphihaline species during the LGM. The migratory allis and twaite shad (Alosa alosa and A. fallax, respectively) and European eel (Anguilla anguilla) disappeared from archaeological sites on the Atlantic drainage basins of France and Cantabria, Spain during the LGM, and probably survived in refugia further to the south (Le Gall, 2008). For the eel, this refugium was probably on the Atlantic coasts of Portugal and Morocco (e.g., Kettle et al., 2008). The glacial refuge of the shad is unclear, but remains have been discovered on the upper Tagus River system at Aridos-1 from the MindelRiss interglacial approximately $300 \mathrm{ka} \mathrm{BP}$ (Morales, 1980; Le Gall, 2000), and it is likely to have survived the LGM on the Iberian Peninsula and northwest Africa. From southern Spain, the boreal gadid species, haddock (Melanogrammus aeglefinus) and pollock (Pollachius pollachius) have been reported by Rodrigo (1994) for the Cueva de Nerja near Malaga dating to the LGM. These results were significant because these species are currently found in northwest Europe, and the southernmost range for haddock and pollock is currently the Bay of Biscay and northern Portugal, respectively (Whitehead et al., 1986). The most recent analyses of the LGM deposits from the Cueva de Nerja have revealed that the northern gadids (including saithe Pollachius virens, cod Gadus morhua, and ling Molva molva) make up more than $30 \%$ of the identified fish remains and thus represented a significant presence among the exploited fish (Cortés-Sánchez et al., 2008; Morales-Muñiz and Roselló-Izquierdo, 2008). The exploitation of gadids continued for an extended period of time after the LGM until the early Holocene as sea levels were returning to present levels and sea surface temperatures approached present values.

Among the most spectacular shifts in species ranges have been reports of the remains of Atlantic salmon (Salmo salar) in archaeological sites from the Mediterranean drainage basins of France, Spain, and Italy dating from the LGM up to the early Holocene. Additional small art objects unambiguously depicting salmon have been located at the Grand Grotte de Bize on a Mediterranean drainage basin (Le Gall, 1994a). These reports from late Palaeolithic-early Mesolithic sites in France, Spain, and Italy (Juan-Muns i Plans, 1985; JuanMuns i Plans et al., 1991) suggest the presence of resident salmon populations in the western Mediterranean Sea. The current southernmost range of Atlantic salmon in northwest Europe is northern Portugal, which indicates that immigrant populations would have had to pass through the Straits of Gibraltar when temperatures in southern Spain during the LGM were similar to northern Europe at present. However, the archaeozoological evidence is contested. Many of the sites in southern France are in proximity to Atlantic drainage basins, and it is possible that the Atlantic salmon remains in the Mediterranean watersheds may have been transported as part of a seasonal migration of fishermen (Le Gall, 1983, 1984, 1992, 1994a, 1994b). This has even been invoked to explain Atlantic salmon finds in the more distant Menton caves on the French-Italian border (Rivière, 1886; Clark, 1948). As well, many of the early identifications of Atlantic salmon at the Caune de Belvis and the Grotte JeanPierre I by Desse and Granier (1976) and at Grimaldi (Barme Grande II) have been subsequently questioned and revised to trout (Salmo trutta) by Le Gall (1994a), Desse-Berset (1994), and Desse and Desse-Berset (2002), respectively. It is difficult to distinguish Atlantic salmon and trout from their skeletal elements, and many of the early salmon identifications were made mainly on the basis of the unusual size of vertebral elements. The revision of the initial identifications may have been made on reflection of the zoogeographic implications of there being endemic Mediterranean Atlantic salmon populations during the LGM. Up until now, the prevailing paradigm has been that the SST in the western Mediterranean during the LGM was too high to meet the oxygen requirements of the species (Le Gall, 1983, 1984, 1994b). On the other hand, recent unambiguous determinations of Atlantic salmon in Solutrean levels in the Cueva de Nerja indicate that ocean temperatures were cool enough during the LGM to permit the passage of the species through the Straits of Gibraltar (Morales-Muñiz and Roselló-Izquierdo, 2008).

Part of the reason why these archaeozoological finds are important is that there are few studies that have investigated how the geographic distribution of marine species changed during the LGM, and most of this is based on molecular markers. Hence, there are few a priori hypotheses of what fish species should be found in archaeozoological collections. This situation contrasts strikingly with the state of knowledge for terrestrial plants and animals and freshwater 
fish, where there is much zooarchaeological and genetic evidence for LGM refugia in southern Europe and recolonization pathways to northern Europe during the Holocene (e.g., Hewitt, 2000; Stewart and Lister, 2001; Provan and Bennett, 2008). Most of the important economic marine fish species have a high gene flow and weak genetic structure that make it difficult to link local population structure with the existence of glacial refugia. Reviewing the genetic structure and LGM history of cod, Pampoulie et al. (2008) speculated that glacial refuge populations survived on the Rockall Plateau, southwest Ireland, and Irminger Sea. However, these predictions are confusing because the LGM SST map of Paul and Schäfer-Neth (2003) suggests that the ocean temperatures and sea ice conditions of these areas may have been too severe to serve as refugia. The issue of assessing the Mediterranean presence of North Atlantic marine species is important not only for determining the glacial refugia of economically important fish, but also for establishing an accurate paradigm for palaeoenvironmental reconstructions using sediment core records. There is currently some uncertainty about the provenance of some North Atlantic planktonic species found in sediment cores of the western Mediterranean, and this represents a puzzle for palaeoenvironmental reconstructions (Rohling et al., 1998).

ENMs attempt to predict the spatial distribution of a species based on databases of climatic (e.g., temperature, rainfall) and other information, and the most robust examples might predict the spatial distribution based on threshold envelopes of temperature, for example, above and below which no viable populations are observed to occur. ENMs have been successfully applied to explain the present-day distributions of some terrestrial species and then carefully calibrated to predict the past distributions during the LGM using palaeoclimatic model data (Waltari et al., 2007). However, for marine species these models have only recently been applied, and for some species, there are sometimes errors in the predictions. The extension of ENMs to explain marine fish distributions during the LGM has recently been performed by Bigg et al. (2008) who used two algorithms to predict the glacial distribution of cod. Although one algorithm, based on a maximum entropy method, predicted suitable LGM habitat along the Atlantic coast of northwest Europe and also large areas of the Mediterranean and the Black Sea, the actual occupation of these areas in southern Europe was judged unlikely because of geographic disjunction. A second algorithm, based on ecophysiological constraints, predicted only limited southward displacement during glacial times, and this clearly shows important disagreements with recent fossil evidence from the Cueva de Nerja in southern Spain (e.g., Cortés-Sánchez et al., 2008; Morales-Muñiz and Roselló-Izquierdo, 2008). Hence, there is still a crucial gap in the understanding of the influence of oceanic conditions that governed the spatial distribution of the marine species during the LGM. The issue is important because future climate warming scenarios predict that the spatial ranges of important species are expected to shift northward (e.g., Perry et al., 2005) and important amphihaline species, like salmon, are predicted to become extinct in the southern parts of their range (Lassalle and Rochard, 2009).

In this contribution, we consider the changes in spatial distribution of four species during the LGM: haddock, pollock, the eastern Atlantic shad species, and Atlantic salmon. Although most marine species must have experienced range changes during the LGM, these four species have been selected mainly because of the long-standing conundrum suggested by the unusual locations of their subfossil evidence. They are also economically important. Of the total European capture production of $\sim 4.4 \times 10^{5}, \sim 3.0 \times 10^{5}$, and $1.2 \times 10^{3}$ tons, for pollock, haddock, and salmon respectively, with a combined value of approximately $26 \%$ of the total US $\$ 6.2$ billion for European fisheries export products (FAO Fishstat Plus v. 2.32; http://www.fao.org/fishery/ statistics/software/fishstat/en). In the Sect. 2 (Methods), we present the current understanding of the environmental requirements of the fish species, together with the ENM algorithms used to determine their present distribution. In Sect. 3 (Results), we present an alternative ENM approach to estimate LGM distributions and use palaeoclimatic SST reconstruction from the LGM to estimate how the species ranges changed. In Sect. 4 (Discussion), we synthesize the information, indicating consistencies between our results and emerging genetic information from other marine species. We point out potentially promising lines of research, and outline how the ENM approach may be used with climate model predictions of future SST changes to assess how fish populations will be displaced.

\section{Methods: an Ecological Niche Model (ENM) based on temperature and bathymetry}

Our predictions of the LGM distribution of marine species are based on a simple ENM that is constructed from the intersection of two environmental conditions (SST and bathymetry). Based on the approximate correspondence between the environmental fields and expert assessments of the species' ranges, we define the approximate present-day envelope of threshold environmental conditions that circumscribes the species niche. Then, we infer the LGM distributions based on published reconstructions of the SST and bathymetry during glacial times. Important advantages of this method of bioclimatic envelopes are: (1) its transparency in the interpretation of a small dataset (Phillips et al., 2006; Ready et al., 2010), and (2) proven track record in predicting modern-day ranges of fish species from imperfect survey data (Ready et al., 2010). Although resource assessments (Kaschner et al., 2006; Lenoir et al., 2010; Ready et al., 2010) and palaeoclimatic reconstructions (Kucera et al., 2005) have followed a statistical approach where large databases have been available, sparse archaeozoological or 


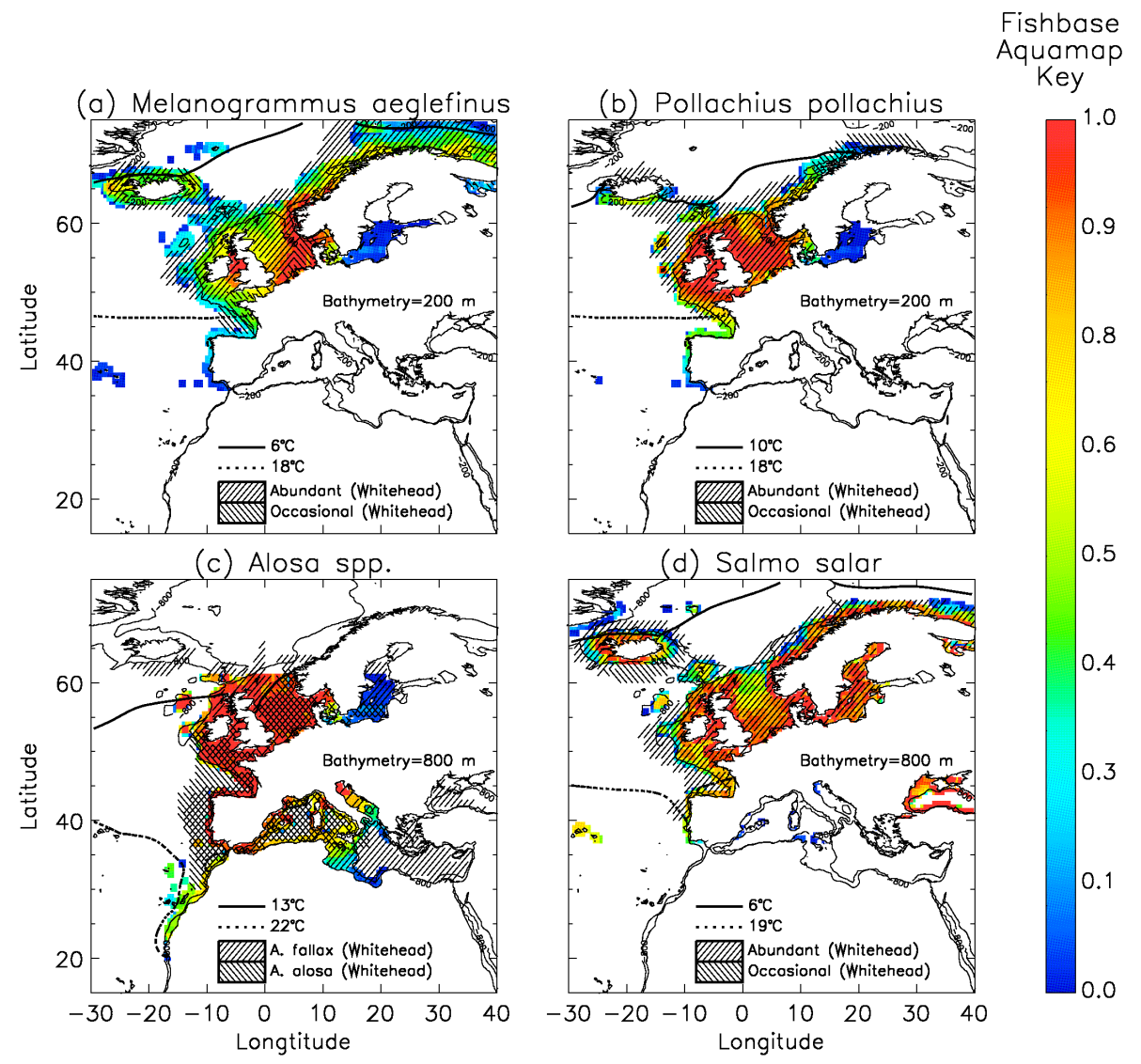

Fig. 1. Spatial distribution of (a) haddock (Melanogrammus aeglefinnus), (b) pollock (Pollachius pollachius), (c) allis and twaite shad (Alosa alosa and Alosa fallax), and (d) Atlantic salmon (Salmo salar). Information is from the Fishbase Aquamap (colour-scale) and atlas of Whitehead et al. (1986; denoted by "Whitehead" and shown by hatching). The Fishbase Aquamap is a metric of relative environmental suitability that is based on the application of environmental envelopes to explain fish survey data in terms of gridded fields of bathymetry, temperature, salinity, ice cover, and primary production (Kaschner et al., 2006; Ready et al., 2010). The bathymetry is from ETOPO-5, with sea level and the single indicated contour $(200 \mathrm{~m}$ or $800 \mathrm{~m})$ plotted on the map. The two shad species are plotted together because their archaeozoological remains are often difficult to distinguish.

palaeontological datasets have value if they contain a striking species ("indicator species" or "guide fossils"; Peacock, 1989) that must indicate certain threshold conditions. This has been exploited in palaeoenvironmental reconstructions further back in time where the data record may not be as rich as for the LGM (e.g., Huber et al., 2000). Following the convention used to assess modern fish resource distributions with large databases (Kaschner et al., 2006; Lenoir et al., 2010; Ready et al., 2010), we have assumed that the salient niche features for the species in our study are captured with each environmental parameter acting independently.

The present day distribution of the four marine and amphihaline species is shown in Fig. 1. Information is available from several sources, but we present expert assessments from two recognized authorities: Fishbase (http://www.fishbase. us/search.php) and Whitehead et al. (1986). Other references are broadly consistent with the chosen expert summaries in terms of the geographic distribution, but may add extra regional information, for example, about where a species may be particularly common (ICES-Fishmap, Haddock, 2009). Presenting only an envelope of presenceabsence information with minimal information about abundance for some species, the information in Whitehead et al. (1986) is the simplest and most robust. The Fishbase Aquamaps present a graded zonation of distribution that is based on sea surface temperature, sea surface salinity (SSS), productivity, bathymetry, and an annual ice cover (see Kaschner et al., 2006 and Ready et al., 2008). Although the extra information implied by the abundance appears useful, the algorithm is calibrated based on survey information, and it may not reproduce expert assessments. For example, for Atlantic salmon in Fig. 1d, there is a predicted distribution in the Mediterranean and Black Seas based on habitat conditions, but the present distributions of wild populations are limited to the Atlantic coasts of northwest Europe as indicated by Whitehead et al. (1986). 


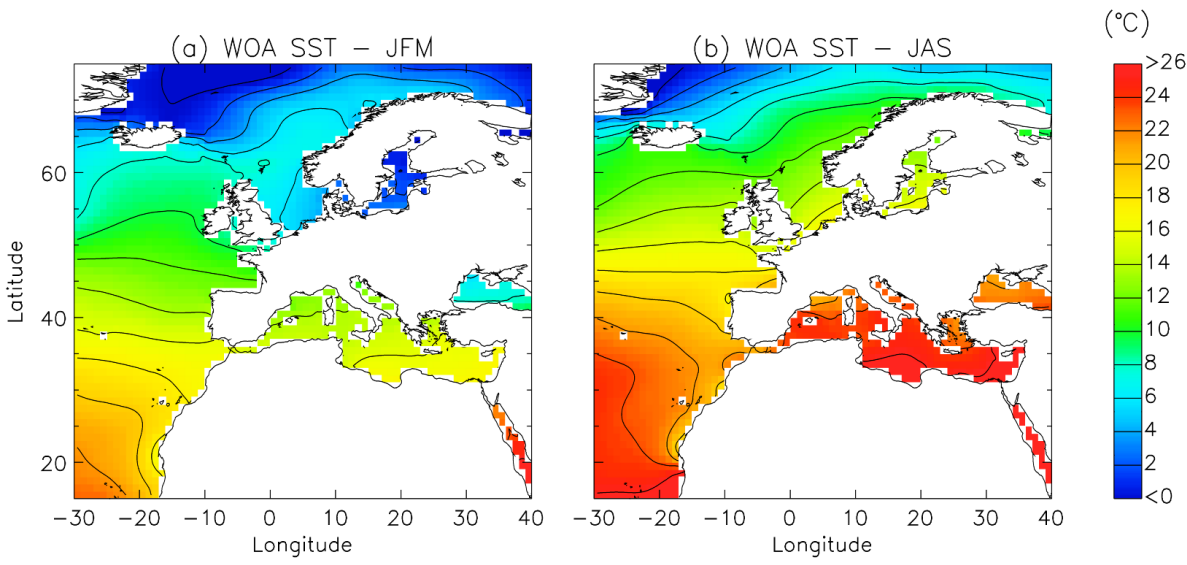

Fig. 2. Climatological sea surface temperature of the northeast Atlantic in (a) winter (January, February, March) and (b) summer (July, August, September) from WOA05 (Levitus, 2006).

The minimum and maximum summertime (July-AugustSeptember, JAS) SST envelopes that define the southern and northern extent of each species are shown in Fig. 1. The SSTs are taken from a present-day climatological atlas at $1^{\circ}$ resolution that is shown in Fig. 2 (from the World Ocean Atlas of Levitus, 2006; abbreviated WOA05). Temperature is recognized as an important determinant of the spatial distribution of fish (Lenoir et al., 2010), and this is grounded on theoretical considerations of oxygen limitation and the temperature-dependence of the metabolic processes (Pörtner, 2001; Pörtner and Knust, 2007). Although species show temperature-dependence at every stage in their life cycle, Bigg et al. (2008) consider temperatures in late spring and early summer as the primary factor affecting the spawning range of cod, and Lenoir et al. (2010) confirm the importance of temperature as a defining criterion for the youngest fish stages. For their ENMs, Bigg et al. (2008) use SST as the metric of the spatial distribution to generate distribution maps. This does not at first seem like an obvious metric for bottom temperature conditions, which are important for a demersal species like cod. On the other hand, the $10^{\circ} \mathrm{C}$ annual average SST isotherm provides an important functional definition of the southern limit of the spatial distribution of cod on both sides of the Atlantic Ocean (Brander, 1996). As well, Lenoir et al. (2010) point out that there is a high correlation between surface temperatures and temperatures at $100 \mathrm{~m}$. This supports the widespread practice in resource studies and palaeoclimatic reconstructions of using SST for the upper ocean conditions to determine species distributions. For our study, we selected the summertime SST (JAS) as the primary criteria defining the spatial distribution of the species, instead of the wintertime (December-January-February, DJF) or annual average SST. In addition to thermal preferences, the species also have a preferred depth habitat (Lenoir et al., 2010), which defines the seaward extent of the range and this has been taken from Fishbase and Whitehead et al. (1986). Along with bathymetry limits (ETOPO-5, http://www.ngdc.noaa.gov/ $\mathrm{mgg} / \mathrm{global} /$ etopo5.HTML), the isotherm envelopes form the basis of the present day distribution ranges shown in Fig. 3. These maps were generated by matching the summertime SST with the species distributions shown in Fig. 1, and a $1^{\circ} \mathrm{C}$ uncertainty in the definition of the thermal envelopes does not change the conclusions of this analysis.

The chosen temperature envelopes are broadly consistent with the temperature thresholds of the four species observed during the field and laboratory studies. For haddock, the ICES-Fishmap (Haddock, 2009) gives a minimum temperature threshold of $6.5^{\circ} \mathrm{C}$, and Brodziak (2005) reports the juvenile and adult fish have been caught during fisheries surveys between temperatures of $2-16^{\circ} \mathrm{C}$. Peck et al. (2003) give the temperature of maximum growth at $12^{\circ} \mathrm{C}$, which is approximately at the center of the summer climatological envelope of $6-18^{\circ} \mathrm{C}$ that has been used to define its range in Fig. 1. For pollock, also a demersal species, the empirically-defined summer climatological SST envelope of $10-18{ }^{\circ} \mathrm{C}$ for the northern and southern range of the species (Fig. 1) is close to the physiological range of temperatures of $9-18^{\circ} \mathrm{C}$, outside of which severe growth decreases are observed (Person-Le Ruyet et al., 2006). These temperatures thresholds for haddock and pollock are broadly consistent with Lenoir et al. (2010) using a statistical analysis of a larger database. For the allis shad, which spawns in freshwater in springtime, the observed migration from the ocean takes place when river temperatures are between $13.3-23^{\circ} \mathrm{C}$ as measured by Acolas et al. (2006), and this defines the proper freshwater environment for spawning and early rearing of young. This observed temperature range is very close to the empirical climatological average summer SSTs that have been used to define the spatial distribution $\left(13-22{ }^{\circ} \mathrm{C}\right.$; shown in Fig. 1c). For the twaite shad the lower temperature envelope may be slightly reduced compared to allis shad to 


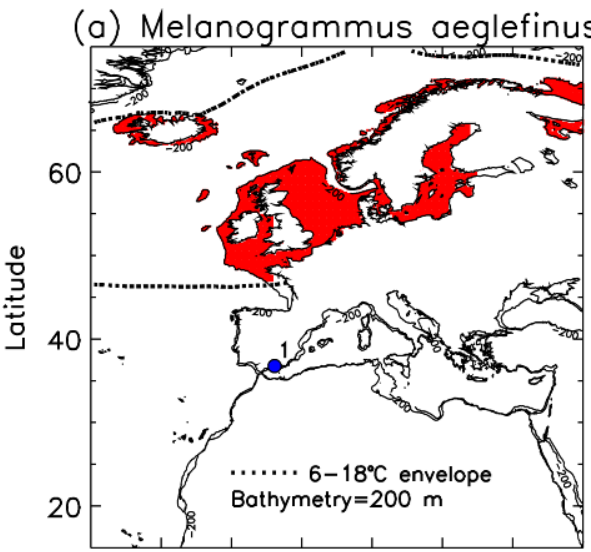

(c) Alosa alosa

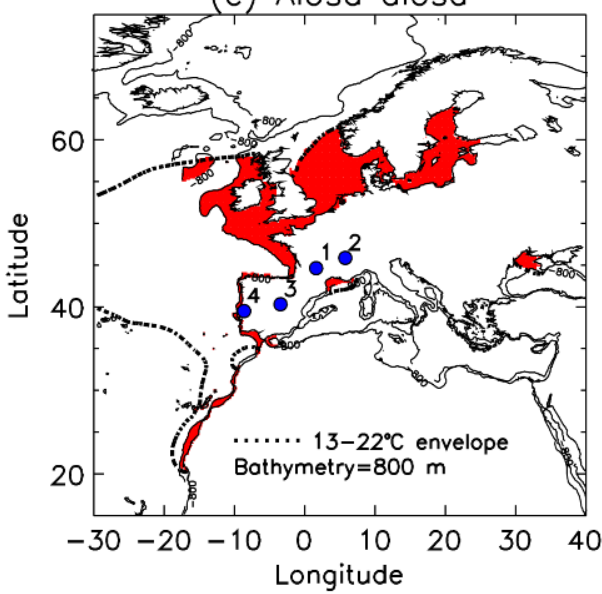

(b) Pollachius pollachius

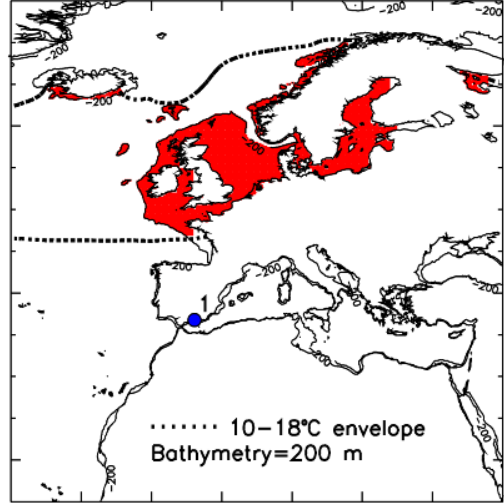

(d) Salmo salar

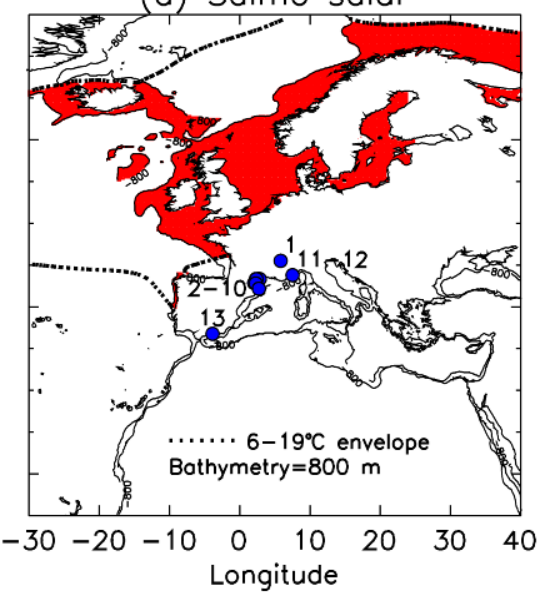

Fig. 3. Simplified species ranges using simplified criteria based on the summer SST and bathymetry envelopes shown in each diagram. The archaeozoological finds are given by blue dots with the number key given in Table 1. For (a) and (b), the archaeological site is 1 . Cueva de Nerja, Spain. For (c), the archaeological sites are 1. Pégourié, Atlantic France, 2. Sous Balme, Mediterranean France, 3. Aridos-1, Spain, and 4. Lapa dos Coelhos, Portugal. For (d), the archaeological sites are 1. Grotte Jean-Pierre I, Mediterranean France, 11. Baoussé-Roussé, Grottes de Menton, Italy, 12. Barme Grande, Grimaldi caves, Italy, 13. Cueva de Nerja, Spain, and a cluster of different sites along the Mediterranean coast of France and Catalonia with labels 2-10. The bathymetry is from ETOPO-5 with sea level and the single additional bathymetric contour indicated on the maps.

explain its more northerly spatial distribution of occasional occurrence in Norway and Iceland (but not spawning at these northern locations).

For Atlantic salmon, the northern and southern boundaries of the range are empirically determined as the $6{ }^{\circ} \mathrm{C}$ and $19^{\circ} \mathrm{C}$ summer SST isotherms (Fig. 1d). There are different possible reasons for this temperature envelope. The fish is highly susceptible at the post-smolt stage just after it migrates from the rivers to the ocean in spring-early summer. Although the mechanism is unclear, stock size is negatively correlated with June SST, and post-smolts are negatively affected by the early arrival of warm ocean temperatures (Friedland et al., 2003). The empirical summer SST envelope is similar to the observed temperature of the downstream migration in Norway in June: $2.5-15.5^{\circ} \mathrm{C}$ (Hvidsten et al., 1998). Another hypothesized mechanism to explain the spatial range of adult salmon relates to its high dissolved oxygen requirements $\left(>7 \mathrm{mg} \mathrm{L}^{-1}\right)$, whose saturation value depends mainly on the temperature but also the salinity of seawater (Le Gall, 1983, 1984). Le Gall (1994b) stated that the southern distribution of the species - and particularly its absence in the Mediterranean - is governed by this oxygen requirement, and the theoretical basis of the temperature dependence of aerobic activity has been more recently clarified by Pörtner and Knust (2007).

Figure 3 also shows the locations of the unusual archaeological features for the time interval from the LGM to the early Holocene (Table 1). For haddock, pollock, and Atlantic salmon, the LGM distribution is far outside of the present ranges, suggesting that there were extreme changes in the past distributions during the glacial periods.

The probable spatial distribution of the fish species during the LGM were independently assessed from LGM SST and bathymetry criteria. Although CLIMAP Project 
Table 1. Location of presence/absence of the remains (or artwork) of haddock, pollock, shad, and Atlantic salmon in pre-Holocene archaeological sites outside their present geographic range. The indices in the table identify the location of the archaeological sites in Figs. 3 and 6. Allis shad (Alosa alosa) and twaite shad (Alosa fallax) are placed together in the table because their archaeozoological remains are often difficult to distinguish. For the time period of the archaeological site, uncal refers to uncalibrated radiocarbon dates. (C. Bonsall reports an error in Table 1 of Pickard and Bonsall, 2004, which shows the Mesolithic remains of allis shad at Advik, Varanger fjord, Norway but is not found in the primary source of Renouf, 1989.)

\begin{tabular}{|c|c|c|c|c|}
\hline Species & & Archaeological site & Time period & Reference \\
\hline $\begin{array}{l}\text { Haddock } \\
\text { (Melanogrammus } \\
\text { aeglefinus) }\end{array}$ & 1 & $\begin{array}{l}\text { Cueva de Nerja, } \\
\text { Spain }\end{array}$ & $\begin{array}{l}\text { LGM/Gravettian and } \\
\text { Solutrean (c. } 24- \\
17.5 \text { ky BP) }\end{array}$ & $\begin{array}{l}\text { Rodrigo (1994), Aura } \\
\text { Tortosa et al. (2002), } \\
\text { Cortéz-Sánchez et al. } \\
\text { (2008), Morales-Muñiz } \\
\text { and Roselló-Izquierdo } \\
\text { (2008) }\end{array}$ \\
\hline $\begin{array}{l}\text { Pollock } \\
\text { (Pollachius } \\
\text { pollachius) }\end{array}$ & 1 & $\begin{array}{l}\text { Cueva de Nerja, } \\
\text { Spain }\end{array}$ & $\begin{array}{l}\text { LGM/Gravettian and } \\
\text { Solutrean (c. } 24- \\
17.5 \text { ky BP) }\end{array}$ & $\begin{array}{l}\text { Rodrigo (1994), Aura } \\
\text { Tortosa et al. (2002), } \\
\text { Cortéz-Sánchez et al. } \\
\text { (2008), Morales-Muñiz } \\
\text { and Roselló-Izquierdo } \\
\text { (2008) }\end{array}$ \\
\hline \multirow[t]{4}{*}{$\begin{array}{l}\text { Shad } \\
\text { (Alosa alosa and } \\
\text { A. fallax) }\end{array}$} & 1 & $\begin{array}{l}\text { Pégourié, Lot, } \\
\text { France (A. alosa in } \\
\text { Atlantic drainage) }\end{array}$ & $\begin{array}{l}\text { Absence during } \\
\text { LGM; small } \\
\text { percentage at level } 7 \\
(12250 \pm 350 \text { uncal } \\
\text { BP); majority of fish } \\
\text { remains at } 11000 \mathrm{BP} \\
\text { in levels } 4-6\end{array}$ & $\begin{array}{l}\text { Le Gall (1993, 1994b, } \\
\text { 1995, 2000), Martin } \\
\text { and Le Gall (2000) }\end{array}$ \\
\hline & 2 & $\begin{array}{l}\text { Sous-Balme, l'Ain, } \\
\text { France (A. alosa or } \\
\text { A. alosa } \\
\text { rhodensias in } \\
\text { Mediterranean } \\
\text { drainage) }\end{array}$ & $\begin{array}{l}\text { Sauveterriens } \\
\text { anciens, } 9000 \mathrm{BP}\end{array}$ & Le Gall (1994b, 2000) \\
\hline & 3 & $\begin{array}{l}\text { Aridos-1, Tagus } \\
\text { River, Spain } \\
\text { (Atlantic drainage) }\end{array}$ & $\begin{array}{l}\text { Mindel-Riss } \\
\text { Interglacial } \\
(\sim 300 \mathrm{k} \mathrm{yr} \mathrm{BP})\end{array}$ & $\begin{array}{l}\text { Morales (1980), } \\
\text { Le Gall (2000) }\end{array}$ \\
\hline & 4 & $\begin{array}{l}\text { Lapa dos Coelhos, } \\
\text { Almonda tributary } \\
\text { of Tagus River, } \\
\text { Portugal }\end{array}$ & Magdalenian & $\begin{array}{l}\text { Roselló and Morales } \\
\text { (2011) }\end{array}$ \\
\hline \multirow[t]{3}{*}{$\begin{array}{l}\text { Atlantic salmon } \\
\text { (Salmo salar) }\end{array}$} & 1 & $\begin{array}{l}\text { Grotte Jean-Pierre I, } \\
\text { Saint-Thibaud- } \\
\text { de-Couz, Savoie, } \\
\text { France }\end{array}$ & $\begin{array}{l}\text { Magdalénien } \\
\text { supérieur à } \\
\text { Mésolithique ancien }\end{array}$ & $\begin{array}{l}\text { Desse and Granier } \\
\text { (1976); evidence } \\
\text { disputed by } \\
\text { Desse-Berset (1994) }\end{array}$ \\
\hline & 2 & $\begin{array}{l}\text { L'Abeurador, } \\
\text { France }\end{array}$ & $\begin{array}{l}\text { Younger Dryas and } \\
\text { Preboreal }\end{array}$ & $\begin{array}{l}\text { Le Gall }(1983,1984, \\
1994 a)\end{array}$ \\
\hline & 3 & $\begin{array}{l}\text { Caune de Belvis, } \\
\text { Aude, France }\end{array}$ & $\begin{array}{l}\text { Levels } 2,3,4 \\
(\sim 12270 \pm 280 \text { uncal } \\
\text { BP })\end{array}$ & $\begin{array}{l}\text { Desse and Granier } \\
\text { (1976), Juan-Muns i } \\
\text { Plans et al. (1991); } \\
\text { evidence disputed by } \\
\text { Le Gall (1994a) }\end{array}$ \\
\hline
\end{tabular}


Table 1. Continued.

\begin{tabular}{|c|c|c|c|c|}
\hline \multirow{2}{*}{\multicolumn{2}{|c|}{ Species }} & & \multirow{2}{*}{$\begin{array}{l}\text { Time period } \\
\text { Upper Magdalenien } \\
(12550 \pm 210 \text { uncal } \\
\text { BP) }\end{array}$} & \multirow{2}{*}{$\begin{array}{l}\text { Reference } \\
\text { Le Gall (1994a), } \\
\text { Le Gall (2001) }\end{array}$} \\
\hline & & $\begin{array}{l}\text { La Grande Grotte } \\
\text { de Bize, Aude, } \\
\text { France (artwork) }\end{array}$ & & \\
\hline & 5 & $\begin{array}{l}\text { Canecaude 1, } \\
\text { Aude, France }\end{array}$ & $\begin{array}{l}\text { Middle Magdalenian } \\
(14230 \pm 160 \text { uncal } \\
\text { BP) }\end{array}$ & Le Gall (1994a) \\
\hline & 6 & $\begin{array}{l}\text { La Grotte Gazel, } \\
\text { Aude, France }\end{array}$ & $\begin{array}{l}\text { Middle } \\
\text { Azilien } \\
\text { Magdalenian- }\end{array}$ & $\begin{array}{l}\text { Costamagno and } \\
\text { Laroulandie (2004; } \\
\text { citing Desse-Berset, } \\
\text { unpublished) }\end{array}$ \\
\hline & 7 & $\begin{array}{l}\text { La Grotte de } \\
\text { l'Oeil, Aude, } \\
\text { France }\end{array}$ & $\begin{array}{l}\text { Upper Magdalenian } \\
\text { (13 800-1 } 300 \text { uncal } \\
\text { BP) }\end{array}$ & $\begin{array}{l}\text { Le Gall (1994a), } \\
\text { Costamagno and } \\
\text { Laroulandie (2004) }\end{array}$ \\
\hline & 8 & $\begin{array}{l}\text { L'Arbreda, } \\
\text { Serinyà, Girona, } \\
\text { Spain }\end{array}$ & Gravettian, Solutrean & $\begin{array}{l}\text { Juan-Muns i Plans } \\
\text { (1985), Juan-Muns } \\
\text { (1987), Juan-Muns i } \\
\text { Plans et al. (1991) }\end{array}$ \\
\hline & 9 & $\begin{array}{l}\text { Davant Pau, } \\
\text { Serinyà, Girona, } \\
\text { Spain }\end{array}$ & Solutrean & $\begin{array}{l}\text { Juan-Muns i Plans } \\
\text { (1985), Juan-Muns i } \\
\text { Plans et al. (1991) }\end{array}$ \\
\hline & 10 & $\begin{array}{l}\text { Reclau Viver, } \\
\text { Serinyà, Girona, } \\
\text { Spain }\end{array}$ & Solutrean & $\begin{array}{l}\text { Juan-Muns i Plans } \\
\text { (1985), Juan-Muns i } \\
\text { Plans et al. (1991) }\end{array}$ \\
\hline & 11 & $\begin{array}{l}\text { Baoussé-Roussé, } \\
\text { Grottes de Menton, } \\
\text { Italy }\end{array}$ & Palaeolithic & Rivières (1886) \\
\hline & 12 & $\begin{array}{l}\text { Barme Grande, } \\
\text { Grimaldi cave, } \\
\text { Italy }\end{array}$ & $?$ & $\begin{array}{l}\text { Juan-Muns i Plans et al. } \\
\text { (1991); citing Clark } \\
\text { (1948) }\end{array}$ \\
\hline & 13 & $\begin{array}{l}\text { Cueva de Nerja, } \\
\text { Spain }\end{array}$ & $\begin{array}{l}\text { Solutrean } \\
(18420 \pm 530, \\
17940 \pm 200, \\
15990 \pm 260 \\
\text { uncal BP })\end{array}$ & $\begin{array}{l}\text { Morales-Muñiz and } \\
\text { Roselló-Izquierdo } \\
\text { (2008) (large Salmo sp } \\
\text { identified as Salmo salar) }\end{array}$ \\
\hline
\end{tabular}

Members (1976) produced the first global view of LGM climate conditions, recent efforts have led to an updated community consensus of LGM conditions. These have been downloaded from the Glacial Ocean Atlas (GOA; http:// www.glacialoceanatlas.org/): the gridded surface data fields of Paul and Schäfer-Neth (2003) and the synthesis dataset of MARGO Project Members (2009). The background of these datasets highlights the unresolved challenges of this field, with the fields of Paul and Schäfer-Neth (2003) representing a compilation of objective measurements and expert opinion to achieve the best guess gridded field that is necessary for a modelling study. By contrast, the dataset of MARGO Project Members (2009) employs a more conservative approach to devise statistics for $5^{\circ} \times 5^{\circ}$ latitude-longitude boxes where data occur, and this means that there are data gaps and resolution problems using the sparse record of deep sea cores.

The spatial interpolation of point determinations of palaeo-SSTs at core locations is still an unresolved problem (Schäfer-Neth et al., 2005). It is important for ENM studies such as ours, which seek to trace a pathway of favorable 


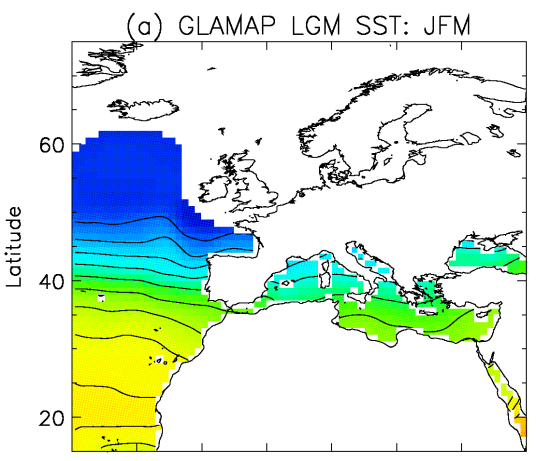

(c) MARGO LGM SST: JFM

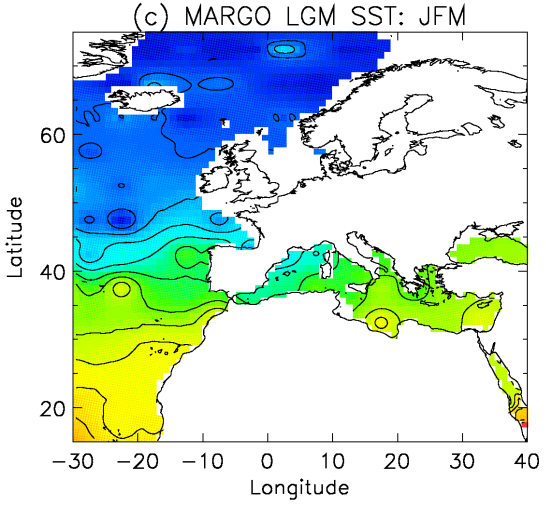

$\left({ }^{\circ} \mathrm{C}\right)$

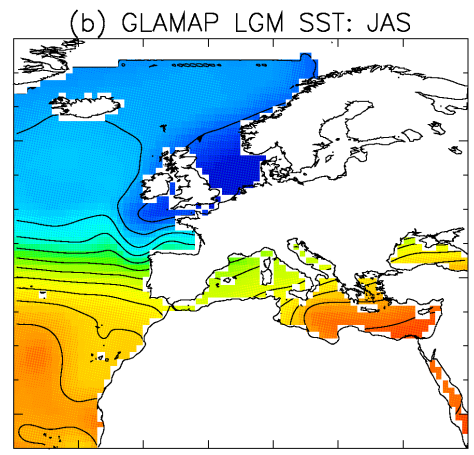

(d) MARGO LGM SST: JAS

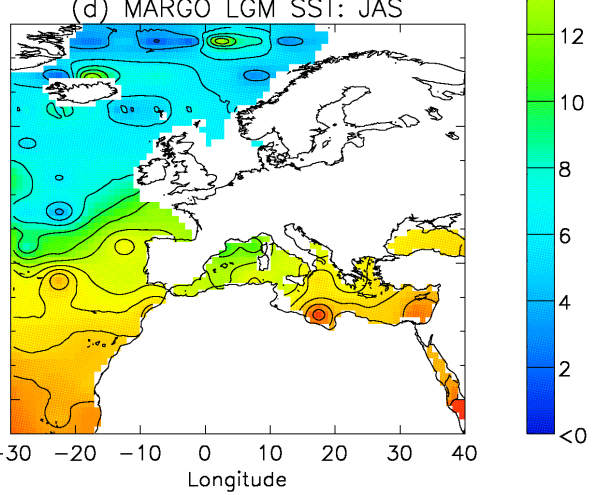

Fig. 4. Climatological SST from the LGM as determined by Paul and Schäfer-Neth (2003) for (a) winter and (b) summer and by MARGO Project Members (2009) for (c) winter and (d) summer. The maps of Paul and Schäfer-Neth (2003) are from the Global Ocean Atlas (GOA; http://www.glacialoceanatlas.org/) and are overplotted with a sea ice template if any of the three months represented in the field have ice cover. The MARGO-interpolated fields (also from GOA) were calculated using a simple interpolation method based on an ${ }^{\circ}$ summary data of MARGO Project Members (2009) with an LGM land template is derived from Peltier (1994) and ETOPO-5 (http://www.ngdc.noaa.gov/ $\mathrm{mgg} / \mathrm{global} /$ etopo5.HTML). No sea ice template was provided with this this dataset.

environmental conditions between ocean basins. The GOA website actually has two sets of fields by Paul and SchäferNeth (2003); one based on expert determinations of the SST isolines and a second based on a kriging interpolation of SST data directly from deep-sea cores. The second set of fields, based on primary data, has been used here. For the data of MARGO Project Members (2009) we have developed an interpolation scheme on a $1^{\circ} \times 1^{\circ}$ grid (with an LGM land template derived from Peltier, 1994) using a weighting factor based on inverse square distance that follows broadly on the WOA05 approach. We consider data within a threshold distance of $1800 \mathrm{~km}$ to ensure that information is propagated from at least one point of the original dataset, and this interpolated product is hereafter referred to as "MARGOinterpolation". Although this simple interpolation scheme does not take account of the preferred zonal projection of information in the North Atlantic Ocean (i.e., as is implicitly assumed by Paul and Schäfer-Neth, 2003, using expert determinations of isolines), the MARGO palaeotemperature information is dense enough that realistic SST fields are produced. Taken together, the fields of Paul and Schäfer-Neth (2003) and MARGO-interpolation represent a range of palaeo-SST conditions to test the predictions of our ENM, and this follows the recommended practice of Nogués-Bravo (2009) to assess the uncertainty of reconstructed palaeoclimate, where this is available.

\section{Results: fish distributions during the Last Glacial Maximum (LGM)}

The two palaeo-SST datasets for the northeast Atlantic from Paul and Schäfer-Neth (2003) and MARGO-interpolation are shown in Fig. 4 for winter (January-February-March) and summer (July-August-September). The difference between the LGM reconstructions and the present day climatology (Fig. 5) illustrates the temperature changes in the northeast Atlantic during the LGM. Most of the mid-latitude areas exhibit some cooling during the LGM, with the most significant decreases around the UK in summer (exceeding $12^{\circ} \mathrm{C}$ for the Paul and Schäfer-Neth, 2003, dataset). In the Mediterranean Sea, temperature decreases are less severe, with $\sim 8-10^{\circ} \mathrm{C}$ summertime decreases in the west and $\sim 4$ $6^{\circ} \mathrm{C}$ summertime decreases in the east. Summer temperature conditions at the Strait of Gibraltar during the LGM 


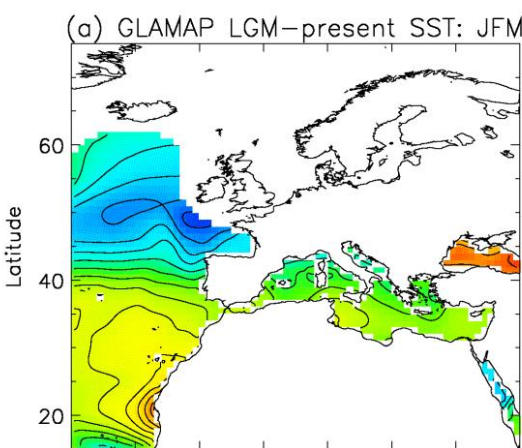

(c) MARGO LGM-present SST: JFM

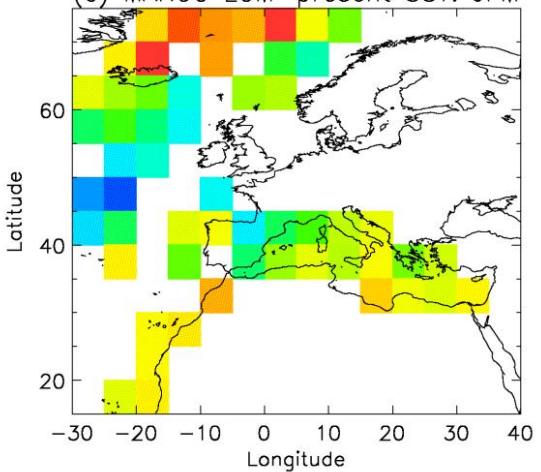

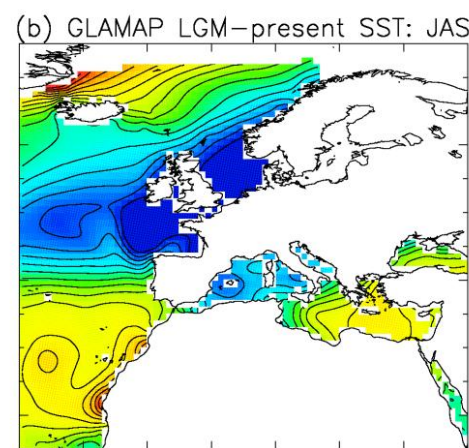

(d) MARGO LGM-present SST: JAS

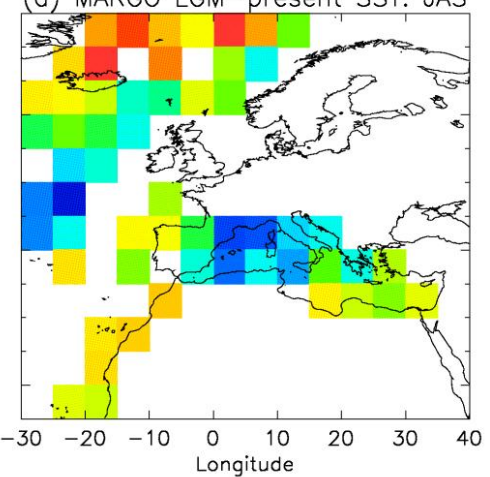

$\left({ }^{\circ} \mathrm{C}\right)$

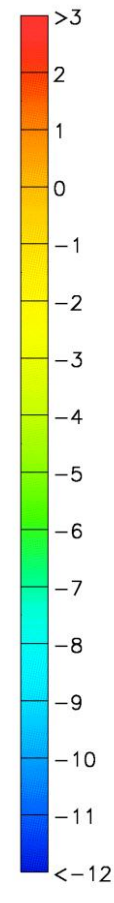

Fig. 5. Difference in climatological SST LGM-present for Paul and Schäfer-Neth (2003) (a) winter and (b) summer and for MARGO Project Members (c) winter and (d) summer. For each palaeo-environmental reconstruction, the present day SST climatology is from the World Ocean Atlas of Levitus (2006).

would have been similar to the south coast of the UK at present. Although the spatial features of the the two palaeoSST reconstructions are broadly similar, the newer information of MARGO Project Members (2009) suggests temperatures of the Nordic Seas were not as cold as depicted by Paul and Schäfer-Neth (2003), while temperatures in the eastern Mediterranean were several degrees cooler than previously believed especially in summer (Hayes et al., 2005).

The LGM distributions of fish species (Figs. 6 and 7) have been assessed using ENMs based on these two palaeoSST fields and the palaeotopography fields of Peltier (1994). All species show a significant southward displacement away from their present ranges, but the cooler palaeo-SST predictions of Paul and Schäfer-Neth (2003) have especially important implications for the location of the LGM northern boundaries. Both ENM results are consistent with the available archaeozoological results. The Cueva de Nerja in the Strait of Gibraltar was well within the estimated LGM range of haddock and pollock, and the ENMs predict that these species may have populated the western Mediterranean Sea as far east as the Adriatic Sea, or even the Aegean Sea according to the MARGO-interpolation fields. The predicted fundamental ecological niche in the Black Sea and Red Sea was probably not realized for the species of this investigation because of geographic disjunction.
Atlantic salmon could likewise swim through the Strait of Gibraltar to form populations in the western Mediterranean Sea, consistent with its archaeozoological presence in the Mediterranean watersheds of Spain, France, and Italy during the LGM. This species is cold-adapted and is found at present in northern Europe as far south as northern Portugal (although there are historical reports of the species as far south as the Guadalquivir River up to 20th century; B. Elvira, personl communication, 2008). Both ENMs for the LGM predict that it maintained a continuous presence on the GirondeDordogne river system through the LGM where its uninterrupted archaeological presence across the LGM has been documented.

The allis shad requires warmer SST conditions, and both ENMs indicates that it was displaced from the Atlantic watersheds of France during the LGM, and this is consistent with its apparent absence from archaeological sites in the Dordogne region (Le Gall, 2008). The recent identification of the remains of (allis) shad in Magdalenian levels of the Lapa dos Coelhos archaeological site on the Tagus watershed of central Portugal gives support to the existence of a glacial refuge in the southern Iberian Peninsula during the LGM (Roselló and Morales, 2010). The model prediction of a theoretical niche extension into the eastern Mediterranean is not much further than its current documented eastern limit 


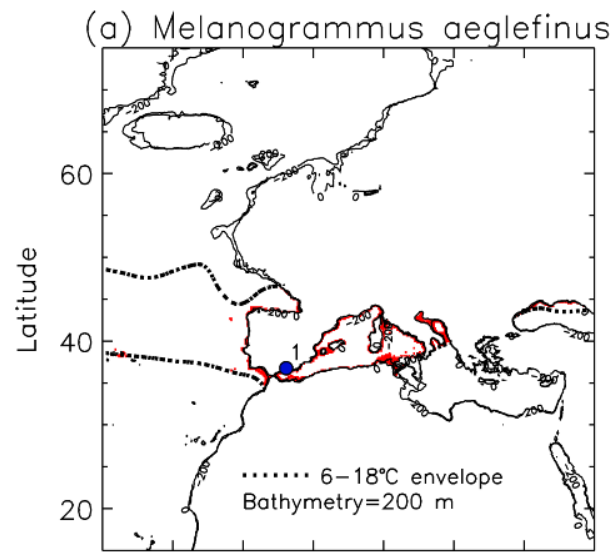

(c) Alosa alosa

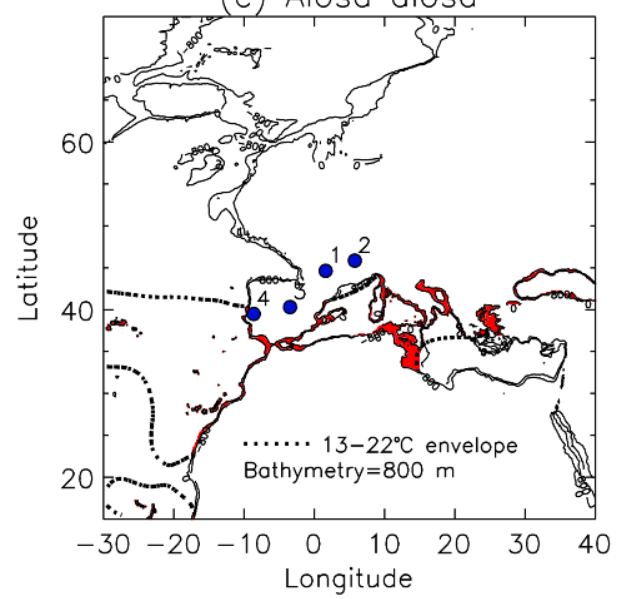

(b) Pollachius pollachius

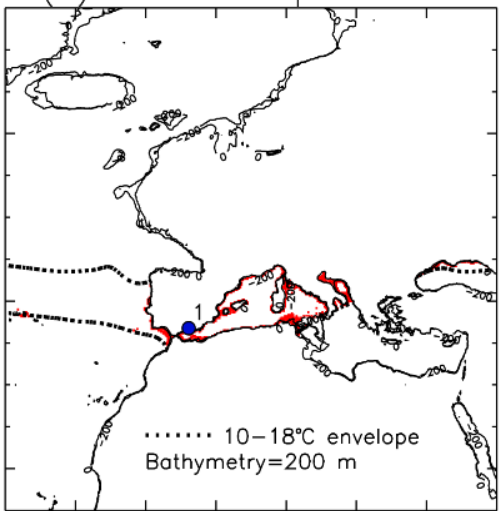

(d) Salmo salar

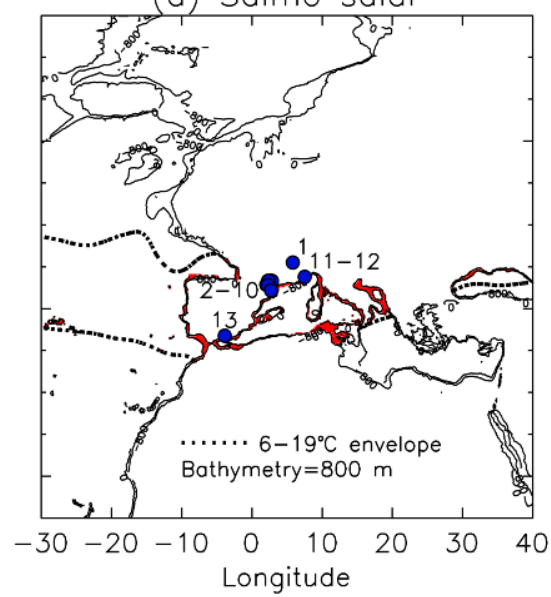

Fig. 6. Predicted species ranges from the LGM reconstruction of Paul and Schäfer-Neth (2003) for (a) haddock, (b) pollock, (c) allis shad, and (d) Atlantic salmon. The ranges are based on the same criteria as for the present distribution in Fig. 3. The archaeological site key is the same as Fig. 3. The LGM ranges within the frame of these maps are 14-33\% of the present day ranges, and the LGM distributions are almost completely shifted away from present-day ranges shown in Fig. 3. The LGM bathymetry is derived from the $1^{\circ}$ sea level data of Peltier (1994) at $21 \mathrm{ka}$ before present, interpolated to the $5^{\prime}$ fields of ETOPO-5. LGM sea level and the single additional bathymetric contour are indicated on the map.

at Sicily, but it is also unclear how much of this fundamental niche would have been occupied with potential competition with other shad species already in the Mediterranean (Nogués-Bravo, 2009).

A second important message in Figs. 6 and 7 is the extent to which the species ranges were reduced during the southern displacement and confined to the continental slope regions. For the Paul and Schäfer-Neth (2003) SST fields in Fig. 6, the LGM ranges were decreased to approximately $19,19,33$, and $14 \%$ of the present range for haddock, pollock, allis shad, and salmon, respectively. For the MARGOinterpolation fields in Fig. 7, the corresponding LGM range was about $53,31,47$, and $39 \%$ of the modern day range. The results for the gadids, haddock and pollock, are broadly consistent with the reduction of the range of cod in the North Atlantic reported by Bigg et al. (2008): 20\% of present day extent. Although the largest contiguous area of species is presently the North Sea, the largest contiguous area for all four species during the LGM may have been the shallow shelf area between Tunisia and Sicily. Significantly, the MARGO-interpolation fields suggest that the cold-adapted species, haddock and salmon, may have maintained a presence in the Nordic seas, although accuracy of the palaeo-SST reconstructions in this region are still uncertain (MARGO Project Members, 2009).

\section{Discussion}

The ENM results presented here give a very different prediction of LGM glacial refuge areas for some of the economically important fish species of northwest Europe compared with the few previous published studies. The main finding is that the glacial refuge of four highly vagile fish species are significantly shifted away from their present biogeographical range mostly in northwest Europe. There is 


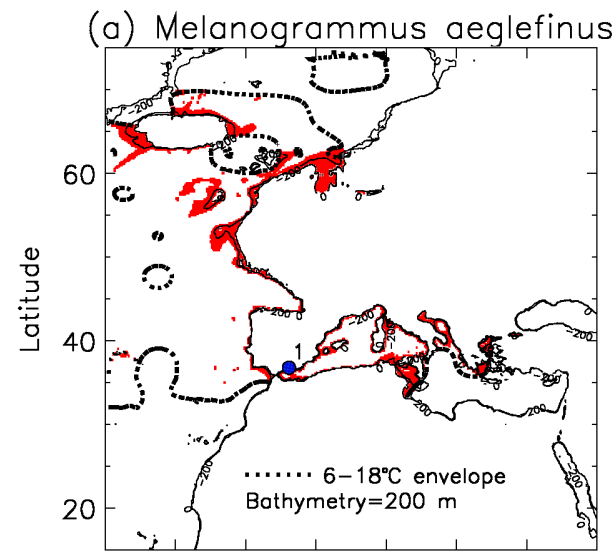

(c) Alosa alosa

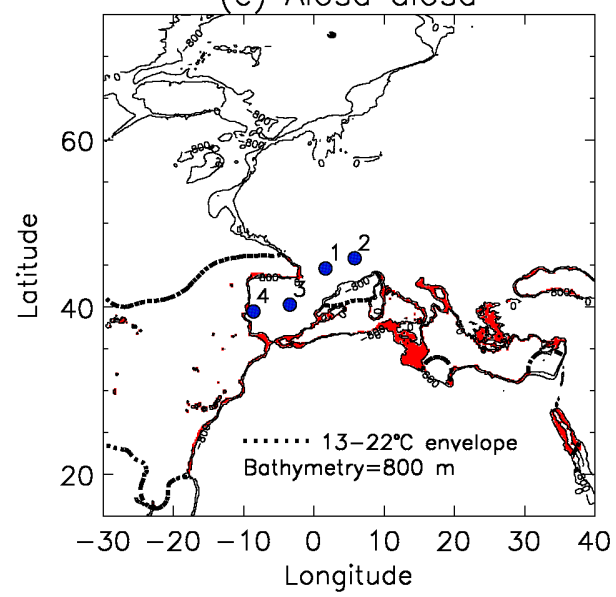

(b) Pollachius pollachius

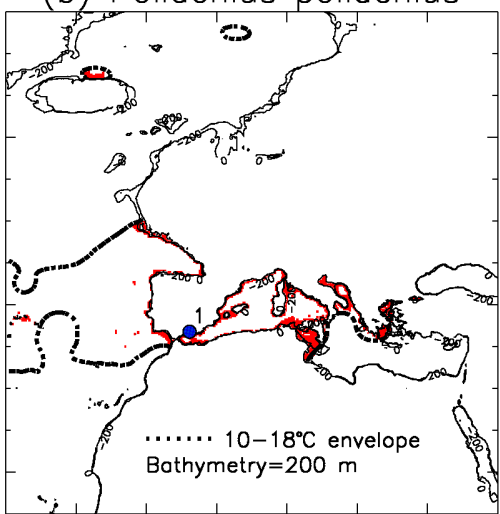

(d) Salmo salar

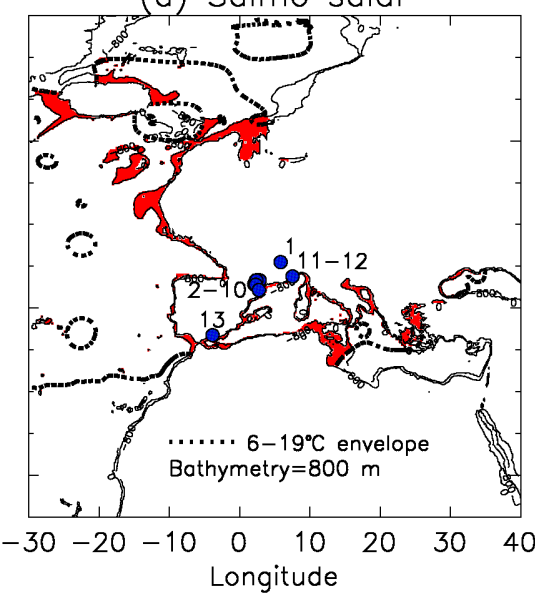

Fig. 7. Predicted species ranges from the LGM reconstruction using the interpolated $5^{\circ} \times 5^{\circ}$ fields of MARGO Project Members (2009) for (a) haddock, (b) pollock, (c) allis shad, and (d) Atlantic salmon. The ranges are based on the same criteria as for the present distribution in Fig. 3. The archaeological site key is the same as Fig. 3. The LGM ranges within the frame of these maps are 31-53\% of the present day ranges, and the LGM distributions are displaced southward from present-day ranges shown in Fig. 3. The LGM bathymetry is derived from the $1^{\circ}$ sea level data of Peltier (1994) at $21 \mathrm{ka}$ before present, interpolated to the $5^{\prime}$ fields of ETOPO-5. LGM sea level and the single additional bathymetric contour are indicated on the map.

strong evidence from two palaeo-SST reconstructions and archaeozoological identifications that cold-adapted gadids and Atlantic salmon invaded the western Mediterranean through the Strait of Gibraltar. The results are startling because the predicted LGM spatial ranges are different from previous assumptions and modelling studies. For example, Pampoulie et al. (2008) speculate that cod survived the LGM on the Rockall Plateau and the Irminger Sea in a reduced subarea of the present range (Fig. 8). Also, the ecophysiological model Bigg et al. (2008) predicted that cod survived the LGM in continental shelf areas of northwest Europe and that populations were displaced only slightly further south compared to the present locations. The predictions of our ENM are supported by subfossil archaeological evidence of the fish species in archaeological sites far to the south of their presently-recognized southern boundaries.

It is difficult to independently verify the predictions of our ENM with genetic information. Molecular markers are not well-suited to elucidating the glacial refugia of highly vagile fish species (Gysels et al., 2004b) like the examples of our study. Highly mobile fish can follow optimal sea temperatures during changing climate conditions, so that the location of their glacial refugia is unclear. This is particularly true for haddock, pollock, and allis shad where the few molecular marker studies have indicated weak population structure among stocks, which was effectively erased during the LGM (see Jamieson and Birley, 1989 and Reiss et al. 2009 for haddock; Charrier et al., 2006 for pollock; and Alexandino and Boisneau, 2000 for shad). For some species, the population age estimated from molecular markers may be inexplicably older than the known length of habitat occupation since the LGM (Francisco et al., 2009). Fish of low dispersal ability are valuable tracers of glacial refugia, and the sand goby (Pomatoschistus minutus) is one such model marine species whose present population structure is a legacy of range constrictions during the glacial period (Gysels et al., 


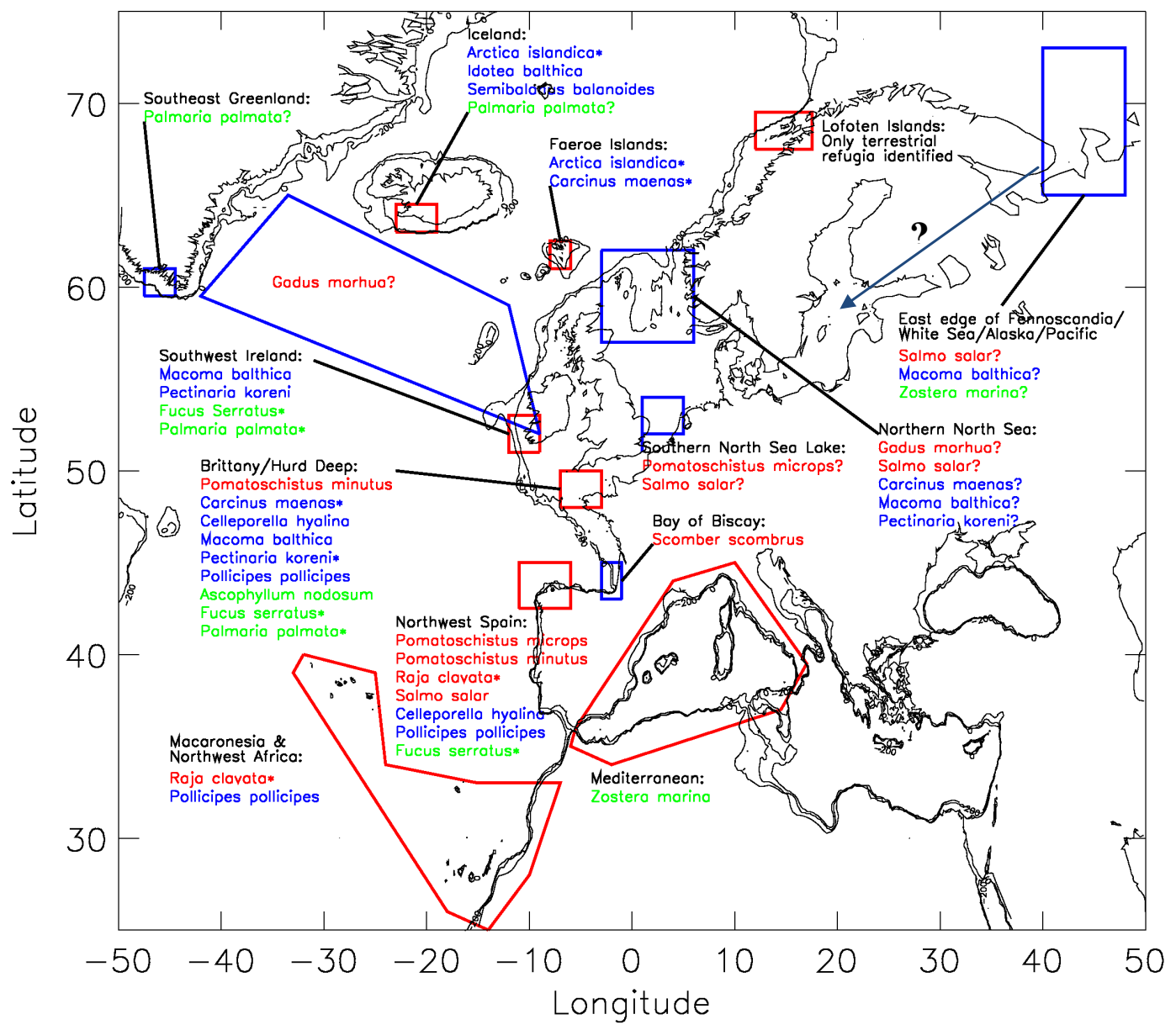

Fig. 8. Marine glacial refugia of plants (green font), invertebrates (blue font), and teleosts (red font), modified from reviews in Gómez et al. (2007), Hoarau et al. (2007), Maggs et al. (2008), Larmuseau et al. (2009) and Olsen et al. (2010), together with their cited primary reports. Thin black lines show the present and LGM coastline, and the $200 \mathrm{~m}$ LGM isobaths. The red boxes present the possible marine refugia reviewed by Maggs et al. (2008). These are supported by a reanalysis of genetics results, except for the Lofoten Islands (i.e., a recognized terrestrial, but not marine, glacial refugium) and the Mediterranean (i.e., a controversial marine refuge area for northeast Atlantic species, Larmuseau et al., 2009, without supporting species in the review of Maggs et al., 2008). The blue boxes and species marked with question marks ? present other speculated marine refugia without firm support from archaeozoological or genetic evidence (e.g., the glacial refugia for Gadus morhua as given in Pampoulie et al., 2008). Marine glacial refugia have identified for plants (Ascophyllum nodosum, Olsen et al., 2010; Fucus serratus, Coyer et al., 2003; Hoarau et al., 2007; Palmaria palmata, Provan et al., 2005; Zostera marina, Olsen et al., 2004), invertebrates (Carcinus maenas, Roman and Palumbi, 2004; Celleporella hyalina, Gómez et al., 2007; Idotea balthica, Wares, 2001; Pectinaria koreni, Jolly et al., 2005, 2006; Macoma balthica, Luttikhuizen et al., 2003; Nikula et al., 2007; Pollicipes pollicipes, Campo et al., 2010; Semibalanus balanoides, Wares and Cunningham, 2001), and teleosts (Pomatoschistus microps, Gysels et al., 2004b; Pomatoschistus minutus, Larmuseau et al., 2009; Raja clavata, Chevolot et al., 2006; Salmo salar, Consuegra et al., 2002; Langefors, 2005; Scomber scombrus, Nesbø et al., 2000). Species marked with an asterisk* have been critically reviewed by Maggs et al. (2008). Some of the unusual (and sometimes diverse) genetic signatures in the North Sea and Baltic are speculated to arise from recolonization from east of the Fennoscandian ice sheet and possibly as far as the Pacific Ocean which was ice-free at high latitudes during the LGM (Olsen et al., 2004).

2004a; Larmuseau et al., 2009). The population has a contiguous distribution in northern Europe, but is fragmented in the Mediterranean, consistent with a species that expanded south during glaciations and retreated northwards during the interglacials as climate conditions became warmer during the Holocene.
For some species, molecular marker studies reveal patterns of recolonization from glacial refugia. Many of the hypothesized refugia in Fig. 8 are located in different parts of southwestern Europe and northwestern Africa, south of the ice sheets and sea ice cover (Fig. 9). The Bay of Biscay, Iberian Peninsula, and Macaronesia (Madeiras, Azores, and Canaries) have all been invoked as glacial refugia of 
various marine species with a present distribution in northwest Europe. This is consistent with the predictions of our SST-based ENMs. However, smaller periglacial refugia - the Hurd Deep near the mouth of the glacial Channel River and southwest Ireland - have also been inferred from genetic evidence for other species. These regions may have been subject to ice cover for part of the year (Fig. 9), but this does not preclude them as glacial refugia for marine species (Gómez et al., 2007). Other refugia have been hypothesized further north in northwest Scotland, northern North Sea, Faeroe Islands, Iceland, and Norway for species adapted to colder conditions and longer sea ice periods (Fig. 9). The identification of some of these glacial refugia pose important questions about the locations of the European ice sheets (Sejrup et al., 2005), which has been identified as an important open question in a recent palaeoclimatological review (Mix et al., 2001).

Atlantic salmon is an important exception whose genetic structure reveals a complex and interesting recolonization history, which introduces another dimension to our results. Our study suggests that Brittany/Hurd Deep was the northernmost range for this species, and that the species was simply displaced southward during the LGM. The unusual genetic structure in the Baltic Sea may have resulted from population isolation during the complex marine transgression history resulting from the interplay of sea level changes and the isostatic rebound in the early Quaternary (Lepiksaar, 2001, p. 40). However, it has also been used to infer recolonization from possible glacial refugia in the southern North Sea or beyond the eastern edge of the Fennoscandian ice sheet (e.g., Consuegra et al., 2002; Langefors, 2005; King et al., 2007; but see also Makhrov et al., 2005). A westward recolonization pathway into the Baltic Sea from the White Sea after the LGM was previously perceived as unlikely. On the other hand, the genetic signatures of the other marine species indicate a possible link between extant populations in the Baltic Sea (and eastern Atlantic) with those further east in the Arctic and Pacific Oceans (Luttikhuizen et al., 2003; Addison and Hart, 2005; Nikula et al., 2007).

The LGM ENM predictions of Bigg et al. (2008) for cod are valuable because the approach is among the first applications of the technique for the marine domain, and it is being used for other North Atlantic species (Provan et al., 2009). Bigg et al. (2008) used two different ENMs for cod that were calibrated to present conditions, and it is important to investigate the possible reasons for the partial discrepancy of their models with our results. The maximum entropy ENM used by Bigg et al. (2008) was based on bathymetry, SST, and SSS. This produced an LGM distribution for cod that stretched from northwest Europe into large areas of the Mediterranean, consistent with the report of archaeozoological remains from the Cueva de Nerja. The ecophysiological ENM incorporated a spawning temperature threshold of 0 $9^{\circ} \mathrm{C}$ between February and June. This is different from the temperature range that we have used for haddock (i.e., an

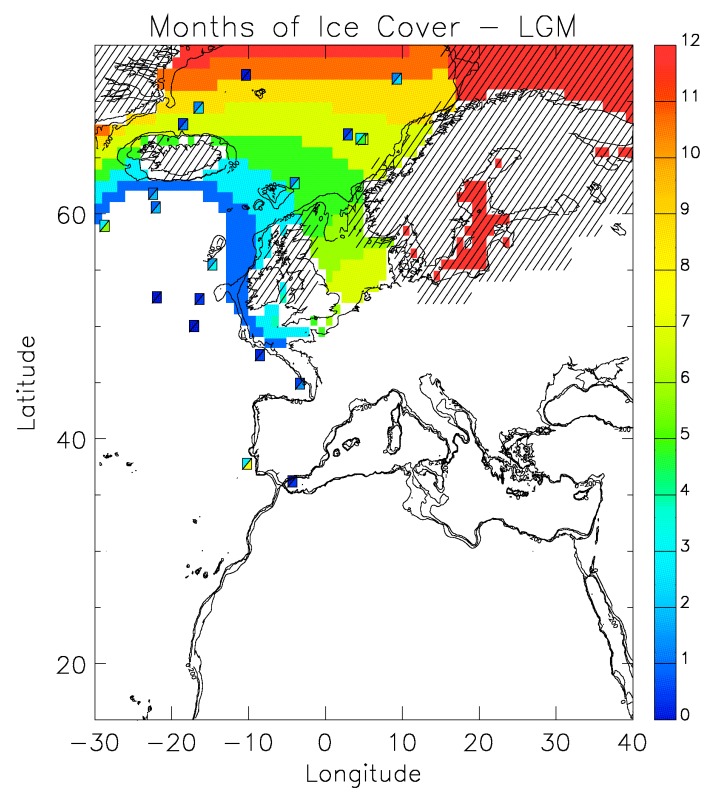

Fig. 9. Months of ice cover from LGM (Paul and Schäfer-Neth, 2003) with glacier template at $21 \mathrm{ka}$ before present indicated by hatching (Peltier, 1994). The LGM bathymetry (sea level and $200 \mathrm{~m}$ depth) is derived from the $1^{\circ}$ sea level data of Peltier (1994) at $21 \mathrm{ka}$ before present, interpolated to the $5^{\prime}$ fields of ETOPO-5. The present-day coastline is indicated on the map. The small boxes give a more recent assessment (De Vernal et al., 2005) of the average number of months of sea ice (top left triangle gives the average number of months; the lower right triangle gives the average-plus-onestandard-deviation). During the LGM, the Nordic seas may have been mostly ice-free during the summer months.

analogous demersal gadid species with a similar range) in Fig. 1a, whose spatial range we have defined to lie between the summertime isotherms of $6-18^{\circ} \mathrm{C}$ (or the $3-12{ }^{\circ} \mathrm{C}$ wintertime isotherms, not shown). The ENM temperature envelope used by Bigg et al. (2008) was slightly lower than our choice. It may have resulted in northern offsets of both the northern and southern present-day species boundaries when evaluated against field surveys, as noted in the original publication. When projected back to the LGM, these thermal envelopes have implications for the predicted glacial refugia. The direct comparison of the different temperature criteria is difficult between the ecophysiological model of Bigg et al. (2008) and the temperature envelopes of our study, partly because strong seasonal variation of the North Atlantic nearsurface ocean temperature. An important message in Bigg et al. (2008) is that the LGM distributions of the marine species can be predicted with just a few parameters (bathymetry and SST), and this is an important feature of robust simplicity that is maintained in our study.

The assumption of "niche stability through time" forms the foundation of all ENM approaches (Nogués-Bravo, 2009), but it has not been addressed by Bigg et al. (2008) or in our study, and it is difficult to prove without a large database of 
independent information to delimit past distributions. For our work, it translates into the assumption that the fish responded to ocean temperature and depth during the LGM in the same way as at present. On the other hand, some evidence indicates that the fish may have changed their behavior in the past for unknown reasons, possibly associated with human exploitation or climate change. For example, Beerenhout (1994) pointed out the remains of full-grown haddock in early Neolithic sites in the Netherlands where they were caught in brackish water estuarine environments. The report is startling because the species is currently subject to commercial exploitation at the northern edge of the North Sea at approximately $200 \mathrm{~m}$ depth (ICES-Fishmap, Haddock, 2009). The Neolithic human populations of the Netherlands did not have the technological means to secure haddock from its 20th century habitat, and there is an important implication that the fish range may have changed to a very different stable state in response to human exploitation. From the late-Palaeolithic period, a similar message is presented by the haddock finds from the Epipalaeolithic levels of the Cueva de Nerja, and these fish were also probably obtained as part of an inshore, shallow-water fishery. Changes in the trophic structure of marine ecosystems have been inferred from changes in species assemblages and sizes based on evidence from Stone Age archaeological sites, and there is an implication that it may have been due to human exploitation (Desse and Desse-Berset, 1993; Morales and Roselló, 2004). This may be linked with alterations in preferred habitats of fish populations. In assessing the possibility of a Mesolithic deep-sea fishery of northern Europe, Pickard and Bonsall (2004) have had to address the provenance of certain species in archaeological sites that presently occur offshore in deep water, and specifically identify bluefin tuna (Thunnus thynnus; i.e., an offshore species with observed spawning migrations inshore), golden redfish (Sebastes marinus), hake (Merluccius merluccius), halibut (Hippoglossus hippoglossus), tusk (Brosme brosme), and wolffish (Anarhichas lupus). Although the authors assume that "the habitat preferences of prehistoric fish populations were broadly similar to those of modern species", the presence of significant numbers of remains of so many deep water species in Mesolithic archaeological sites, forces consideration that the fish may have changed their habitat preferences. This is not mere speculation since strong fishing pressure has been repeatedly documented to provoke changes in the behaviour of fish populations (Perry et al., 2010; Planque et al., 2010). Alternatively, such shifts may have been provoked by the systematic fishing of inshore populations that may have led to local extinctions of those living in the shallowest and most accessible waters. Indeed, the aforementioned studies (Perry et al., 2010; Planque et al., 2010) reveal that vital demographic parameters of fish populations, such as a shorter life cycle, can be a response to a systematic fishing of the largest specimens, making certain stocks more vulnerable to extinction. This could have been most easily achieved on the most accessible biotopes (e.g., estuaries, shallow waters, etc.) where, even without a particularly high fishing pressure, removal of such fishes could bring about the cascade of changes leading to the extinction of a not-too-large population.

The results of our study represent an evolving picture of the marine species distributions that will be revised with future work on palaeoclimatic environmental reconstructions and modelling activities. Palaeoclimatic reconstructions of SST have evolved since the initial CLIMAP Project Members (1976) assessments, but there are still ocean areas where the LGM assessments of SST and SSS are unclear and where different proxy methods may disagree (MARGO Project Members, 2009). On the other hand, from the archaeozoological perspective, there appears to be a convergence of evidence for the climatic conditions in the Mediterranean basin during the LGM. The LGM SST reconstruction in Figs. 4 and 5 indicates that whereas western Mediterranean SST conditions decreased drastically and were low enough to support populations of northern gadids and Atlantic salmon, annual average SSTs in the eastern Mediterranean were only about $1.5-3{ }^{\circ} \mathrm{C}$ cooler than present (Hayes et al., 2005). Marine ecosystems in the eastern Mediterranean did not experience the same intense cooling conditions as in the western basin, and SSTs may have been similar to modern conditions. The new LGM temperature reconstructions force a departure from an earlier paradigm that SSTs were too warm to permit the migration of these species through the Strait of Gibraltar (e.g., Le Gall, 1994b). Rather than a barrier at the Strait of Gibraltar, our ENM indicates that there may have been an important thermal boundary in the middle of the Mediterranean at Sicily, and this is consistent with the genetic studies of other marine species that show an important division at Tunisia-Sicily saddle (Domingues et al., 2005). Likewise, the predicted LGM range of the species of our study indicate that there may have been a geographic disjunction between the western Mediterranean and the Adriatic Sea. This highlights that our ENM can only predict the fundamental ecological niche, and the realized niche in the Adriatic Sea and eastern Mediterranean remains less certain. On the other hand, the significance of the barrier represented by the Italian Peninsula on the free migration between populations in the western Mediterranean and the Adriatic Sea may help to explain the distinct genetic signatures of certain marine species in these two basins (Gysels et al., 2004a; Debes et al., 2008; Maggio et al., 2009).

Future experimental work may aim to verify the predictions of the ENM that have been presented here. For example, genetic studies might aim to determine the structure of the vanished populations in the Mediterranean (Nielsen and Hansen, 2008). For the archaeological LGM Atlantic salmon population in northern Spain, Consuegra et al. (2002) found a dominant haplotype that has almost vanished from modern populations in the region. However, the question of the genetic structure of the hypothesized LGM salmon populations in the Mediterranean is open. The amount of exchange 
through the Straits of Gibraltar during the LGM is unknown, and it is not clear if the Mediterranean population, at the extreme of the species' range, had the opportunity to develop its own genetic signature.

Our ENMs make predictions about the extent of the expansion of haddock, pollock, allis shad, and Atlantic salmon into the central Mediterranean that can only be unequivocally resolved with further archaeozoological studies. The ENMs effectively explain observations of LGM fish species distributions at the Strait of Gibraltar and in southern France. However, there is some ambiguity about the ENM predictions at the extremes of the ranges in the eastern Mediterranean, along west Africa, and in the Nordic Seas, and this is due partly to the uncertainty in the SST reconstructions in these areas. Where the palaeoclimatic information in deep sea cores is equivocal, archaeozoological information may help to reduce the large uncertainty in LGM SST reconstructions especially in the Nordic Seas, whose summertime LGM SST is between the minimum temperature envelopes delimiting the northern range of the different species considered in our study. For example, the large differences in the ENM range predictions for haddock in the Nordic Seas during the LGM are due to the different SST reconstructions, and a single archaeozoological find of haddock in the contested region would help resolve the differences between the maps of Paul and Schäfer-Neth (2003) and MARGO Project Members (2009). Although LGM archaeological sites with the remains of marine fish are uncommon, an alternative approach is the quantification of fish otoliths from shallow sediment cores on the continental shelf. The concept has been explored by Elder et al. (1996) who used the otoliths of a small fish species Ceratoscopelus maderensis off the eastern seaboard of the United States to demonstrate significant changes in its range between glacial and postglacial times. Cod (i.e., a larger fish with a lower population density) otoliths were also identified in their bottom samples, and highlight possibility of using this species to discriminate between different SST reconstructions. There is also potential evidence from the mollusc remains in shallow marine deposits and archaeological sites. Malatesta and Zarlenga (1986) cite many examples of indicator molluscs ("Northern Guests") as evidence of repeated species invasions (and retreats) of the Mediterranean Sea from northwest Europe during the coldest intervals of the Pleistocene glaciations. For example, the range of the Atlantic quahog (Arctica islandica) extended into the western Mediterranean Sea during the LGM, but the species became extinct in its southern European domain approximately 9800 years BP and currently does not survive south of Brittany (Froget et al., 1972; Dahlgren et al., 2000). Along with the invasion of Atlantic fish through the Strait of Gibraltar during the LGM, the presence of these molluscs may force a re-interpretation of LGM planktonic ecosystem assemblages from sediment cores in the western Mediterranean (Rohling et al., 1998). Although ENMs and genetic evidence provide indications of past species' ranges, physical evidence provided by fossil or subfossil material provides the most unambiguous identification of actual glacial refugia.

Ultimately, the importance of understanding the past distributions of economic species during the LGM is to assess their thermal niche and predict how their ranges might change with future climate warming. Analyzing fish survey time series from the North Sea, Perry et al. (2005) calculated that the ranges of demersal species have shifted north approximately $170 \mathrm{~km}$ between 1962-2001. Other studies present evidence of rapid range shifts on the order of several thousand kilometers over a few years for such pelagic species as sardines and anchovies, due to their nonterritorial behaviour and higher dispersal capabilities (McFarlane et al., 2000; Beare et al., 2004). Predictions of future temperature increases have been used to predict the extinction of migratory species from the southern parts of their ranges (e.g., Lassalle and Rochard, 2009), but the calibration of these models depends on how species responded to climatic temperature perturbations in the past. The results presented here capture the southern displacement of certain marine species during the LGM. The warm conditions during the mid-Holocene warm period offer a potential proxy for future climate warming. At this time, warm water species like the European sea bass ( $D i$ centrarchus labrax) were displaced from their historicallyrecognized range south of the British Isles to become economically important for the Mesolithic cultures of Denmark (e.g. Enghoff et al., 2007) and the German Baltic Sea coast (Heinrich, 2001; Schmölcke et al., 2006). Likewise, the Atlantic quahog, whose present northern distribution stops at the White Sea, ranged to Spitsbergen, western Greenland and far across the northern coast of Russia during the warmer climate conditions of the mid-Holocene (Dahlgren et al., 2000). The archaeozoological evidence thus provides critical data to predict how the spatial ranges of marine species may change in the coming decades and centuries.

Acknowledgements. We thank K. Uehara for supplying high resolution palaeotopography fields. We appreciate the helpful comments of M. Kucera, A. Paul, and one anonymous reviewer that have improved this work.

Edited by: André Paul

\section{References}

Acolas, M. L., Veron, V., Jourdan, H., Begout, M. L., Sabatie, M. R., and Baglinière, J. L.: Upstream migration and reproductive patterns of a population of allis shad in a small river (L'Aulne, Brittany, France), ICES J. Mar. Sci., 63, 476-484, doi:10.1016/j.icesjms.2004.07.023, 2006.

Addison, J. A. and Hart, M. W.: Colonization, dispersal, and hybridization influence phylogeography of North Atlantic sea urchins (Strongylocentrotus droebachiensis), Evolution, 59, 532-543, doi:10.1554/04-238, 2005. 
Alexandrino, P. and Boisneau, P.: 8. Diversité génétique, in: Les Aloses (Alosa alosa et Alosa fallax spp.), Ecobiologie et Variabilité des Populations, edited by: Baglinière, J.-L. and Elie, P., Institut National de la Recherche Agronomique (INRA), Paris, 179-198, 2000.

Aura Tortosa, J. E., Jordá Pardo, J. F., Pérez Ripoll, M., Rodrigo García, M. J., Badal García, E., and Guillem Calatayud, P.: The far south: the Pleistocene-Holocene transition in Nerja Cave (Andalucía, Spain), Quatern. Int., 93-94, 19-30, doi:10.1016/S1040-6182(02)00004-6, 2002.

Beare, D. J., Burns, F., Grieg, A., Jones, E. G., Peach, K., Kienzle, M., McKenzie, E., and Reid, D. G.: Long-term increases in prevalence of North Sea fishes having southern biogeographic affinities, Mar. Ecol.-Prog. Ser., 284, 269-278, 2004.

Beaugrand, G. and Reid, P. C.: Long-term changes in phytoplankton, zooplankton and salmon related to climate, Global Change Biol., 9, 801-817, doi:10.1046/j.1365-2486.2003.00632.x, 2003.

Beerenhout, B.: What conclusions can be drawn from mature haddock bones in a Neolithic site in the Netherlands, Offa, 51, 341347, 1994.

Belyea, L. R.: Revealing the Emperor's new clothes: nichebased palaeoenvironmental reconstruction in the light of recent ecological theory, Holocene, 17, 683-688, doi:10.1177/0959683607079002, 2007.

Bigg, G. R., Cunningham, C. W., Ottersen, G., Pogson, G. H., Wadley, M. R., and Williamson, P.: Ice-age survival of Atlantic cod: agreement between palaeoecology and genetics, P. Roy. Soc. B-Biol. Sci., 275, 163-172, doi:10.1098/rspb.2007.1153, 2008.

Bradley, R. S.: Paleoclimatology. Reconstructing Climates of the Quaternary, Academic Press, San Diego, 1999.

Brander, K.: Effects of climate change on cod (Gadus morhua) stocks, in: Global Warming: Implications for freshwater and marine fish, edited by: Wood, C. M. and McDonald, D. G., Society for Experimental Biology Seminar Series 61, Cambridge University Press, 255-278, 1996.

Brodziak, J. K. T.: Haddock, Melanogrammus aeglefinnus, Life History and Habitat Characteristics, NOAA Technical Memorandum NMFS-NE-196, US Department of Commerce, December, 2005.

Butzer, K. W.: Environment and Archaeology, Aldine Publishing Company, Chicago, 1964.

Campo, D., Molares, J., Garcia, L., Fernandez-Rueda, P., Garcia-Gonzalez, C., and Garcia-Vazquez, E.: Phylogeography of the European stalked barnacle (Pollicipes pollicipes): identification of glacial refugia, Mol. Biol., 157, 147-156, doi:10.1007/s00227-009-1305-z, 2010.

Charrier, G., Durand, J.-D., Quiniou, L., and Laroche, J.: An investigation of the population structure of pollack (Pollachius pollachius) based on microsatellite markers, ICES J. Mar. Sci., 63, 1705-1709, doi:10.1016/j.icesjms.2006.07.006, 2006.

Chevolot, M., Hoarau, G., Rijnsdorp, A. D., and Stam, W. T.: Phylogeography and population structure of thornback rays (Raja clavata L., Rajidae), Mol. Ecol., 15, 3693-3705, doi:10.1111/j.1365-294X.2006.03043.x, 2006.

Clark, J. G. D.: The development of fishing in prehistoric Europe, Antiq. J., 28, 45-85, 1948.
CLIMAP Project Members: The surface of the ice-age Earth, Science, 191, 1131-1137, doi:10.1126/science.191.4232.1131, 1976.

Consuegra, S., García de Leániz, C., Serdio, A., González Morales, M., Straus, L. G., Knox, D., and Verspoor, E.: Mitochondrial DNA variation in Pleistocene and modern Atlantic salmon from the Iberian glacial refugium, Mol. Ecol., 11, 2037-2048, doi:10.1046/j.1365-294X.2002.01592.x, 2002.

Cortés-Sánchez, M., Morales-Muñiz, A., Simón-Vallejo, M. D., Bergadà-Zapata, M. M., Delgado-Huertas, A., López-García, P., López-Sáez, J. A., Lozano-Francisco, M. C., Riquelme-Cantal, J. A., Roselló-Izquierdo, E., Sánchez-Marco, A., and VeraPeláez, J. L.: Palaeoenvironmental and cultural dynamics of the coast of Málaga (Andalusia, Spain) during the Upper Pleistocene and early Holocene, Quaternary Sci. Rev., 27, 2176-2193, doi:10.1016/j.quascirev.2008.03.010, 2008.

Costamagno, S. and Laroulandie, V.: L'exploitation des petits vertébrés dans les Pyrénées françaises du Paléolithique au Mésolithique: un inventaire taphonomique et archéozoologique, in: Petits Animaux et Sociétés Humaines, du Complement Alimentaire aux Ressources Utilitaires, edited by: Brugal, J.-P., and Desse, J., XXIV ${ }^{e}$ rencontres internationales d'archéologie et d'histoire d'Antibes, Éditions APDCA, Antibes, 403-416, 2004.

Coyer, J. A., Peters, A. F., Stam, W. T., and Olsen, J. L.: Post-ice age recolonization and differentiation of Fucus serratus L. (Phaeophyceae; Fucuceae) populations in Northern Europe, Mol. Ecol., 12, 1817-1829, doi:10.1046/j.1365-294X.2003.01850.x, 2003.

Dahlgren, T. G., Weinberg, J. R., and Halanych, K. M.: Phylogeography of the ocean quahog (Arctica islandica): influences of paleoclimate on genetic diversity and species range, Mar. Biol., 137, 487-495, doi:10.1007/s002270000342, 2000.

De Vernal, A., Eynaud, F., Henry, M., Hillaire-Marcel, C., Londeix, L., Mangin, S., Matteissen, J., Marret, F., Radi, T., Rochon, A., Solignac, S., and Turon, J.-L.: Reconstruction of seasurface conditions at middle to high latitudes of the Northern Hemisphere during the Last Glacial Maximum (LGM) based on dinoflagellate cyst assemblages, Quaternary Sci. Rev., 24, 897924, 2005.

Debes, P. V., Zachos, F. E., and Hanel, R.: Mitochondrial phylogeography of the European sprat (Sprattus sprattus L., Clupeidae) reveals isolated climatically vulnerable populations in the Mediterranean Sea and range expansion in the northeast Atlantic, Mol. Ecol., 17, 3873-3888, doi:10.1111/j.1365294X.2008.03872.x, 2008.

Desse, G. and Granier, J.: Les poissons, in: La Préhistoire française, I, 1, CNRS, Paris, 437-441, 1976.

Desse, J. and Desse-Berset, N.: Pêche et surpêche en Méditerranée: le témoignage des os, in: Exploitation des animaux sauvages à travers le temps, actes des XIII ${ }^{e}$ Rencontres internationals d'archéologie et d'histoire d'Antibes, Octobre 1992, Antibes, Éditions APDCA, 327-339, 1993.

Desse, J. and Desse-Berset, N.: Le cortège de Neptune: les poissons de la Mediterranée durant l'Holocène, in: Mouvements ou déplacements de populations animales en Mediterranée au cours de l'Holocène, edited by: Gardeisen, A., Séminaire, France, 29 Septembre 2000, BAR International Series 1017, 83-96, 2002. 
Desse-Berset, N.: Les poissons, in: Les grottes Jean-Pierre I et II à Saint-Thibaud-de-Couz (Savoie), edited by: Bintz, P., Gallia Préhistoire, 36, 218-224, 1994.

Domingues, V. S., Bucciarelli, G., Almada, V. C., and Bernardi, G.: Historical colonization and demography of the Mediterranean damselfish, Chromis chromis, Mol. Ecol., 14, 4051-4063, doi:10.1111/j.1365-294X.2005.02723.x, 2005.

Elder, K. L., Jones, G. A., and Bolz, G.: Distribution of otoliths in surficial sediments of the U.S. Atlantic continental shelf and slope and potential for reconstructing Holocene climate, Paleoceanography, 11, 359-367, doi:10.1029/96PA00042, 1996.

Enghoff, I. B., MacKenzie, B. R., and Nielsen, E. E.: The Danish fish fauna during the warm Atlantic period (ca. 70003900 BC): Forerunner of future changes?, Fish. Res., 87, 167180, doi:10.1016/j.fishres.2007.03.004, 2007.

Francisco, S. M., Castilho, R., Soares, M., Congiu, L., Brito, A., Vieira, M. N., and Almada, V. C.: Phylogeography and demographic history of Atherina presbyter (Pisces: Atherinidae) in the North-eastern Atlantic based on mitochondrial DNA, Mar. Biol., 156, 1421-1432, doi:10.1007/s00227-009-1182-5, 2009.

Friedland, K. D., Reddin, D. G., and Castonguay, M.: Oceanic thermal conditions in the post-smolt nursery of North Atlantic salmon, ICES J. Mar. Sci., 60, 343-355, doi:10.1016/S10543139(03)00022-5, 2003.

Froget, C., Thommeret, J., and Thommeret, Y.: Mollusques septentrionaux en Méditerranée occidentale: datation par le ${ }^{14} \mathrm{C}$, Palaeogeogr. Palaeocl., 12, 285-293, 1972.

Gómez, A., Hughes, R. N., Wright, P. J., Carvalho, G. R., and Lunt, D. H.: Mitochondrial DNA phylogeography and mating compatibility reveal marked genetic structuring and speciation in the NE Atlantic bryozoans Celleporella hyaline, Mol. Ecol., 16, 2173-2188, doi:10.1111/j.1365-294X.2007.03308.x, 2007.

Gysels, E. S., Hellemans, B., Patarnello, T., and Volckaert, F. A. M.: Current and historic gene flow of the sand goby Pomastoschistus minutus on the European Continental Shelf and in the Mediterranean Sea, Biol. J. Linn. Soc., 83, 561-576, doi:10.1111/j.10958312.2004.00411.x,2004a.

Gysels, E. S., Hellemans, B., Pampoulie, C., and Volckaert, F. A. M.: Phylogeography of the common goby, Pomatoschistus microps, with particular emphasis on the colonization of the Mediterranean and the North Sea, Mol. Ecol., 13, 403-417, doi:10.1046/j.1365-294X.2003.02087.x, 2004b.

Hayes, A., Kucera, M., Kallel, N., Sbaffi, L., and Rohling, E.J.: Glacial Mediterranean sea surface temperatures based on planktonic formaminiferal assemblages, Quaternary Sci. Rev., 24, 999-1016, doi:10.1016/j.quascirev.2004.02.018, 2005.

Heinrich, D.: Bemerkungen zu den Tierknochenfunden von den submarinen Siedlungsplätzen der Ertebølle-Kultur bei Timmendorf/Poel und bei Neustadt (Marienbad) - ein Vorbericht, Beiträge zur Archäozoologie und Prähistorischen Anthropologie, 3, 39-43, 2001.

Hewitt, G.: The genetic legacy of the Quaternary ice ages, Nature, 405, 907-913, doi:10.1038/35016000, 2000.

Hoarau, G., Coyer, J.A., Veldsink, J.H., Stam, W.T., and Olsen, J.L.: Glacial refugia and recolonization pathways in the brown seaweed Fucus serratus, Mol. Ecol., 16, 3606-3616, doi:10.1111/j.1365-294X.2007.03408.x, 2007.

Huber, B. T., MacLeod, K. G., and Wing, S. L.: Warm Climates in Earth History, Cambridge University Press, Cambridge, 2000.
Hvidsten, N. A., Heggberget, T. G., and Jensen, A. J.: Sea water temperatures at Atlantic salmon smolt enterance, Nord. J. Freshwater Res., 74, 79-86, 1998.

ICES-FishMap: Haddock (WWW document), http://www.ices. $\mathrm{dk} /$ marineworld/fishmap/ices/pdf/haddock.pdf (last access: 1 March 2011), 2009.

Jamieson, A. and Birley, A. J., The distribution of transferrin alleles in haddock stocks, J. Cons. Int. Explor. Mer, 45, 248-262, doi:10.1093/icesjms/45.3.248, 1989.

Jolly, M. T., Jollivet, D., Gentil, F., Thiébaut, E., and Viard, F.: Sharp genetic break between Atlantic and English Channel populations of the polychaete Pectinaria koreni, along the North coast of France, Heredity, 94, 23-32, doi:10.1038/sj.hdy.6800543, 2005.

Jolly, M. T., Viard, F., Gentil, F., Thiébaut, E., and Jollivet, D.: Comparative phylogeography of two coastal polychaete tubeworms in the North East Atlantic supports shared history and vicariant events, Mol. Ecol., 15, 1841-1855, doi:10.1111/j.1365294X.2006.02910.x, 2006.

Juan-Muns i Plans, N.: La ictiofauna dels jaciments arqueològics Catalans, Cypsela, Girona, V, 21-33, 1985.

Juan-Muns, N.: La ictiofauna de la cova de l'Arbreda (Serinyà, Girona), Cypsela (Girona), VI, 97-100, 1987.

Juan-Muns i Plans, N., Rodrigo García, M. J., and Rodríguez Santana, C. G.: La ictiofauna de los yacimientos arqueológicos, Sus posilidades en la reconstrucción paleoecológica y de interpretación paleoeconómica, Arqueología, Madrid, 83-99, 1991.

Kaschner, K., Watson, R., Trites, A. W., and Pauly, D.: Mapping world-wide distributions of marine mammal species using a relative environmental suitability (RES) model, Mar. Ecol.-Prog. Ser., 316, 285-310, doi:10.3354/meps316285, 2006.

Kettle, A. J., Heinrich, D., Barrett, J. H., Benecke, N., and Locker, A.: Past distributions of the European freshwater eel from archaeological doi:10.1016/j.quascirev.2008.03.005, 2008.

King, T. L., Verspoor, E., Spidle, A. P., Gross, R., Phillips, R. B., Koljonen, M.-L., Sanchez, J. A., and Morrison, C. L.: 5. Biodiversity and population structure, in: The Atlantic salmon, Genetics, conser, J. L., Blackwell Publishing, Oxford, 117-166, 2007.

Kucera, M., Weinelt, M., Kiefer, T., Pflaumann, U., Hayes, A., Weinelt, M., Chen, M.-T., Mix, A. C., Barrows, T. T., Cortijo, E., Duprat, J., Juggins, S., and Waelbroeck, C.: Recontruction of sea-surface temperatures from assemblages of planktonic foraminifera: multi-technique approach based on geographically constrained calibration data sets and its application to glacial Atlantic and Pacific Oceans, Quaternary Sci. Rev., 24, 951-998, doi:10.1016/j.quascirev.2004.07.014, 2005.

Langefors, A. H.: Adaptive and neutral genetic variation and colonization history of Atlantic salmon, Salmo salar, Environ. Biol. Fish., 74, 297-308, doi:10.1007/s10641-005-0501-z, 2005.

Larmuseau, M. H. D., Van Houdt, J. K. J., Guelinckx, J., Hellemans, B., and Volckaert, F. A. M.: Distributional and demographic consequences of Pleistocene climate fluctuations for a marine demersal fish in the north-eastern Atlantic, J. Biogeogr., 36, 11381151, doi:10.1111/j.1365-2699.2008.02072.x, 2009.

Lassalle, G. and Rochard, E.: Impact of twenty-first century climate change on diadromous fish spread over Europe, North Africa and the Middle East, Glob. Change Biol., 15, 1072-1089, doi:10.1111/j.1365-2486.2008.01794.x, 2009. 
Le Gall, O.: Presence de vestiges de saumon Atlantique dans un site Epipaleolithique et Mesolithique du bassin versant Mediterranean, Bulletin du Société d'Anthropologie de Sud-Ouest, XVIII, 53-55, 1983.

Le Gall, O.: L'Exploitation de l'ichthyofaune par les paléolithiques quelques exemples., in: N. Desse-Berset (Ed.): 2nd Fish Osteoarchaeology Meeting, Table Rond, Sophia Antipolis - Valbonne, 14-16 Octobre 1983, CNRS, Centres de Recherches Archéologiques, Notes et Monographies Techniques No. 16, 89112, 1984.

Le Gall, O.: Poissons et pêches au Paléolithique (Quelques données de l'Europe occidentale), L'Anthopologie, Paris, 96, 121-134, 1992.

Le Gall, O.: Évolution des pêches de l'Épipaléolithique au Néolithique Ancien, in: Préhistoire Anthropologie Mediterranéenes, LAPMO, Université de Provence, CNRS, 2, 135-142, 1993.

Le Gall, O.: Eléments de réflexion sur la pêche dans le bassin méditerranéen nord-occidental pendant le développement des faciès leptolithiques, $\mathrm{XXIV}^{e}$ Congrès Préhistorique de France Carcassonne 26-30 Septembre 1994 - Les faciès leptolithiques du nord-ouest méditerranéen: milieux naturels et culturels, 251265, 1994a.

Le Gall, O.: Quelques remarques sur l'adaptation à court et à long termes chez les poissons d'eau douce du sud de la France, in: Fish Exploitation in the Past, edited by: Van Neer, W., Proceedings of the 7th meetings of the ICAZ Fish Remains Working Group, Annales du Musée Royal de l'Afrique Centrale, Sciences Zoologiques, no. 274, Turvuren, 91-98, 1994b.

Le Gall, O.: Études des Poissons, in: La Grotte de Pégourié, Caniac-du-Causse (Lot), edited by: Séronie-Vivien, M.-R., Préhistoire Quercinoise, Supplément no. 2, 149-154, 1995.

Le Gall, O.: 6. Origine et histoire des aloses, in: Les Aloses (Alosa alosa et Alosa fallax spp.), edited by: Baglinière, J. L. and Elie, P.: Écobiologie et variabilité des populations, INRA, Paris, 127136, 2000.

Le Gall, O.: Les représentations de poissons dans l'art mobilier magdalenien, Une expression de l'importance culturelle de la pêche, Bulletin Préhistoire du Sud-Ouest, no. 8, 55-69, 2001.

Le Gall, O.: Les poissons des eaux douces pléistocènes sont-ils des indicateurs paleoclimatiques? Une approche élargie à l'Europe, in: Archéologie du Poisson, 30 Ans d'Archéo-Ichtyologie au CNRS, edited by: Béarez, P., Grouard, S., and Clavel, B., Hommage aux travaux de Jean Desse et Nathalie Desse-Berset, XIVth ICAZ Fish remains working group meeting, Éditions APDCA, Antibes, 311-326, 2008.

Lenoir, S., Beaugrand, G., and Lecuyer, É.: Modelled spatial distribution of marine fish and projected modifications in the North Atlantic Ocean, Global Change Biol., 17, 115-129, doi:10.1111/j.1365-2486.2010.02229.x, 2011.

Lepiksaar, J.: Die spät- und postglaziale Faunengeschichte der Süßwasserfische Schwedens, Oetker-Voges Verlag, Kiel, 2001.

Levitus, S.: World Ocean Atlas 2005, NOAA Atlas NESDIS, US Government Printing Office, Washington, DC, http: //www.nodc.noaa.gov/OC5/WOA05/pr_woa05.html (last access: 1 March 2011), 2006.

Luttikhuizen, P. C., Drent, J., and Baker, A. J.: Disjunct distribution of highly diverged mitochondrial lineage clade and population subdivision in a marine bivalve with pelagic larval dispersal, Mol. Ecol., 12, 2215-2229, doi:10.1046/j.1365294X.2003.01872.x, 2003.

Maggio, T., Brutto, S. L., Garoia, F., Tinti, F., and Arculeo, M.: Microsatellite analysis of red mullet Mullus barbatus (Perciformes, Mullidae) reveals the isolation of the Adriatic Basin in the Mediterranean Sea, ICES J. Mar. Sci., 66, 1883-1891, 2009.

Maggs, C. A., Castilho, R., Foltz, D., Henzler, C., Jolly, M. T., Kelly, J., Olsen, J., Perez, K. E., Stam, W., Väinölä, R., Viard, F., and Wares, J.: Evaluating signatures of glacial refugia for North Atlantic benthic marine taxa, Ecology, 89 Supplement, S108S122, doi:10.1890/08-0257.1, 2008.

Makhrov, A. A., Verspoor, E., Artamonova, V. S., and O'Sullivan, M.: Atlantic salmon colonization of the Russian Arctic coast: pioneers from North America, J. Fish Biol., 67 (Supplement A), 68-79, doi:10.1111/j.0022-1112.2005.00840.x, 2005.

Malatesta, A. and Zarlenga, F.: Northern guests in the Pleistocene Mediterranean Sea, Geologica Romana, 25, 91-154, 1986.

MARGO Project Members: Constraints on the magnitude and patterns of ocean cooling at the Last Glacial Maximum, Nat. Geosci., 2, 127-132, doi:10.1038/ngeo411, 2009.

Martin, H. and Le Gall, O.: La faune: un indicateur des comportements humains. La chasse de cerf au Post-Paléolithique: deux exemples, Anthropologie et Préhistoire, 111, 364-369, 2000.

McFarlane, G. A., King, J. R., and Beamish, R. J.: Have there been recent changes in climate? Ask the fish, Prog. Oceanogr., 47, 147-169, doi:10.1016/S0079-6611(00)00034-3, 2000.

Mix, A. C., Bard, E., and Schneider, R.: Environmental processes of the ice age: land, oceans, glaciers (EPILOG), Quaternary Sci. Rev., 20, 627-657, 2001.

Morales, A.: Los peces fosiles del yacimiento achelense de Aridos1 (Arganda, Madrid), in: Ocupaciones achelenses en el Valle del Jarama, edited by: Santonja, M. and López, N., Madrid, 93-104, 1980.

Morales, A. and Roselló, E.: Fishing down the food web in Iberian prehistory? A new look at the fishes from Cueva de Nerja (Málaga, Spain), in: Petits Animaux et Sociétés Humaines, Du Complément Alimentaire aux Ressources Utilitaires, edited by: Brugal, J.-P. and Desse, J., XXIV ${ }^{\mathrm{e}}$ rencontres internationals d'archéologie et d'histoire d'Antibes, Éditions APDCA, Antibes, 111-123, 2004.

Morales-Muñiz, A. and Roselló-Izquierdo, E.: Twenty thousand years of fishing in the Strait, in: Human Impacts on Ancient Marine Ecosystems, A Global Perspective, edited by: Rick, T. C. and Erlandson, J. M., University of California Press, Berkeley, 243-277, 2008.

Nesb $\varnothing$, C. L., Rueness, E. K., Iversen, S. A., Skagen, D. W., and Jakobsen, K. S.: Phylogeography and population history of Atlantic mackerel (Scomber scombrus L.): a genealogical approach reveals genetic structuring among the eastern Atlantic stocks, P. Roy. Soc. B-Biol. Sci., 267, 281-292, doi:10.1098/rspb.2000.0998, 2000.

Nielsen, E. E. and Hansen, M. M.: Waking the dead: the value of population genetic analyses of historical samples, Fish Fish., 9, 450-461, doi:10.1111/j.1467-2979.2008.00304.x, 2008.

Nikula, R., Strelkov, P., and Väinölä, R.: Diversity and trans-Arctic invasion history of mitochondrial lineages in the North Atlantic Macoma balthica complex (bivalvia: tellinidae), Evolution, 61, 928-941, doi:10.1111/j.1558-5646.2007.00066.x, 2007. 
Nogués-Bravo, D.: Predicting the past distribution of species climatic niches, Global Ecol. Biogeogr., 18, 521-531, doi:10.1111/j.1466-8238.2009.00476.x, 2009.

Olsen, J. L., Stam, W. T., Coyer, J. A., Reusch, T. B. H., Billingham, M., Boström, C., Calvert, E., Christie, H., Granger, S., La Lumière, R., Milchakova, N., Oudot-Le Secq, M.-P., Procaccini, G., Sanjabi, B., Serrão, E., Veldsink, J., Widdicombe, S., and Wyllie-Echverria, S.: North Atlantic phylogeography and large-scale population differentiation of the seagrass Zostera marina L., Mol. Ecol., 13, 1923-1941, doi:10.1111/j.1365294X.2004.02205.x, 2004.

Olsen, J. L., Zechman, F. W., Hoarau, G., Coyer, J. A., Stam, W. T., Valero, M., and Åberg, P.: The phylogeographic architecture of the fucoid seaweed Ascophyllum nodosum: an intertidal "marine tree" and survivor of more than one glacial-interglacial cycle, J. Biogeogr., 37, 842-856, doi:10.1111/j.1365-2699.2009.02262.x, 2010.

Pampoulie, C., Stefánsson, M. Ö., Jörundsdóttir, T. D., Danilowicz, B. S., and Daníelsdóttir, A. K.: Recolonization history and large-scale dispersal in the open sea: the case study of the North Atlantic cod, Gadus morhua L., Biol. J. Linn. Soc., 94, 315-329, doi:10.1111/j.1095-8312.2008.00995.x, 2008.

Paul, A. and Schäfer-Neth, C.: Modeling the water masses of the Atlantic Ocean at the Last Glacial Maximum, Paleoceanography, 18, 1058, doi:10.1029/2002PA000783, 2003.

Peacock, J. D.: Marine molluscs and late Quaternary environmental studies with particular reference to the late-glacial period in northwest Europe: a review, Quaternary Sci. Rev., 8, 179-192, doi:10.1016/0277-3791(89)90006-1, 1989

Peck, M. A., Buckley, L. J., Caldarone, E. M., and Bengtson, D. A.: Effects of food consumption and temperature on growth rate and biochemical-based indicators of growth in early juvenile Atlantic cod Gadus morhua and haddock Melanogrammus aeglefinus, Mar. Ecol.-Prog. Ser., 251, 233-243, doi:10.3354/meps251233, 2003.

Peltier, W. R.: Ice-age paleotopography, Science, 265, 195-201, doi:10.1126/science.265.5169.195, 1994.

Perry, A. L., Low, P. J., Ellis, J. R., and Reynolds, J. D.: Climate change and distribution shifts in marine fishes, Science, 308, 1912-1915, doi:10.1126/science.1111322, 2005.

Perry, R. I., Cury, P., Brander, K., Jennings, S., Möllmann, C., and Planque, B.: Sensitivity of marine systems to climate and fishing: Concepts, issues and management responses, J. Mar. Syst., 79, 427-435, doi:10.1016/j.jmarsys.2008.12.017, 2010.

Person-Le Ruyet, J., Buchet, V., Vincent, B., Le Delliou, H., and Quemener, L.: Effects of temperature on the growth of pollack (Pollachius pollachius) juveniles, Aquaculture, 251, 340-345, doi:10.1016/j.aquaculture.2005.06.029, 2006.

Phillips, S. J., Anderson, R. P., and Schapire, R. E.: Maximum entropy modeling of species geographic distributions, Ecol. Modell., 190, 231-259, doi:10.1016/j.ecolmodel.2005.03.026, 2006.

Pickard, C. and Bonsall, C.: Deep-sea fishing in the European Mesolithic: fact for fantasy?, Eur. J. Archaeol., 7, 273-290, doi:10.1177/1461957104056504, 2004.

Planque, B., Fromentin, J.-M., Cury, P., Drinkwater, K. F., Jennings, S., Perry, R. I., and Kifani, S.: How does fishing alter marine populations and ecosystems sensitivity to climate?, J. Mar. Syst., 79, 408-417, doi:10.1016/j.jmarsys.2008.12.018, 2010.
Pörtner, H. O.: Climate change and temperature-dependent biogeography: oxygen limitation of thermal tolerance in animals, Naturwissenschaften, 88, 137-146, doi:10.1007/s001140100216, 2001.

Pörtner, H. O. and Knust, R.: Climate change affects marine fishes through the oxygen limitation of thermal tolerance, Science, 315, 95-97, doi:10.1126/science.1135471, 2007.

Provan, J. and Bennett, K. D.: Phylogeographic insights into cryptic glacial refugia, Trends Ecol. Evol., 23, 564-571, doi:10.1016/j.tree.2008.06.010, 2008.

Provan, J., Wattier, R. A., and Maggs, C. A.: Phylogeographic analysis of the red seaweed Palmaria palmata reveals a Pleistocene marine glacial refugium in the English Channel, Mol. Ecol., 14, 793-803, doi:10.1111/j.1365-294X.2005.02447.x, 2005.

Provan, J., Beatty, G. E., Keating, S. L., Maggs, C. A., and Savidge, G.: High dispersal potential has maintained long-term population stability in the North Atlantic copepod Calanus finmarchicus, P. Roy. Soc. B-Biol. Soc., 276, 301-307, doi:10.1098/rspb.2008.1062, 2009.

Ready, J., Kaschner, K., South, A. B., Eastwood, P. D., Rees, T., Rius, J., Agbayani, E., Kullander, S., and Froese, R.: Predicting the distributions of marine organisms at the global scale, Ecol. Modell., 221, 467-478, doi:10.1016/j.ecolmodel.2009.10.025, 2010.

Reiss, H., Hoarau, G., Dickey-Collas, M., and Wolff, W. J.: Genetic population structure of marine fish: mismatch between biological and fisheries management units, Fish and Fisheries, 10, 361-395, doi:10.1111/j.1467-2979.2008.00324.x, 2009.

Renouf, M. A. P.: Prehistoric Hunter-Fishers of Varangerfjord, Northeastern Norway, Brit. Archaeol. Rep. In., 478, Oxford, 1989.

Rivière, E.: Faune des oiseaux, des reptiles et des poissons trouvés dans les cavernes des Baoussé-Roussé (Italie) dites Grottes de Menton, Materiaux pour l'Histoire Primitive et Naturelle de l'Homme, 20, 525-535, 1886.

Rodrigo, M. J.: Remains of Melanogrammus aeglefinus (Linnaeus, 1758 ) in the Pleistocene - Holocene passage in the cave of Nerja, Málaga/Spain, Offa, 51, 348-351, 1994.

Rohling, E. J., Hayes, A., De Rijk, S., Kroon, D., Zachariasse, W. J., and Eisma, D.: Abrupt cold spells in the northwest Mediterranean, Paleoceanography, 13, 316-322, doi:10.1029/98PA00671, 1998.

Roman, J. and Palumbi, S. R.: A global invader at home: population structure of the green crab, Carcinus maenus, in Europe, Mol. Ecol., 13, 2891-2898, doi:10.1111/j.1365-294X.2004.02255.x, 2004.

Roselló, E. and Morales, A.: Lapa dos Coelhos: informe sobre los restos de peces, in: Homenaje a Francisco Giles Pacheco, edited by: Mata, E., Publicaciones Junta de Andalucia, Sevilla, 261276, 2010.

Sarnthein, M., Gersonde, R., Niebler, S., Pflaumann, U., Spielhagen, R., Thiede, J., Wefer, G., and Weinelt, M.: Overview of Glacial Atlantic Ocean Mapping (GLAMAP 2000), Paleoceanography, 18, 1030, doi:10.1029/2002PA000769, 2003.

Schäfer-Neth, C., Paul, A., and Mulitza, S.: Perspectives on mapping the MARGO reconstructions by variogram analysis/kriging and objective analysis, Quaternary Sci. Rev., 24, 1083-1093, doi:10.1016/j.quascirev.2004.06.017, 2005. 
Schmölcke, U., Endtmann, E., Kloos, S., Meyer, M., Michaelis, D., Rickert, B.-H., and Rössler, D.: Changes of sea level, landscape and culture: a review of the south-western Baltic area between 8800 and 4000 BC, Palaeogeogr. Palaeocl., 240, 423-438, doi:10.1016/j.palaeo.2006.02.009, 2006.

Sejrup, H. P., Hjelstuen, B. O., Dahlgren, K. I. T., Haflidason, H., Kuijpers, A., Nygård, A., Praeg, D., Stoker, M. S., and Vorren, T. O.: Pleistocene glacial history of the NW European continental margin, Mar. Petrol. Geol., 22, 1111-1129, doi:10.1016/j.marpetgeo.2004.09.007, 2005.

Stewart, J. R. and Lister, A. M.: Cryptic northern refugia and the origins of the modern biota, Trends Ecol. Evol., 16, 608-613, doi:10.1016/S0169-5347(01)02338-2, 2001.
Waltari, E., Hijmans, R. J., Peterson, A. T., Nyári, A. S., Perkins, S. L., and Guralnick, R. P.: Locating Pleistocene refugia: competing phylogeographic and ecological niche model predictions, PLoS ONE, 2, e563., doi:10.1371/journal.pone.0000563, 2007.

Wares, J. P.: Intraspecific variation and geographic isolation in Idotea balthica (Isopoda: valvifera), J. Crustacean Biol., 21, 1007-1013, doi:10.1651/02780372(2001)021[1007:IVAGII]2.0.CO;2, 2001.

Wares, J. P. and Cunningham, C. W.: Phylogeography and historical ecology of the North Atlantic intertidal, Evolution, 55, 2455-2469, doi:10.1554/00143820(2001)055[2455:PAHEOT]2.0.CO;2, 2001.

Whitehead, P. J. P., Bauchot, M. L., Hureau, J. C., Nielsen, J., and Tortonese, E.: Fishes of the North-eastern Atlantic and the Mediterranean, UNESCO, Paris, 1986. 